\title{
Global differences in vitamin D status and dietary intake: a review of the data
}

\author{
Kevin D Cashman \\ Cork Centre for Vitamin D and Nutrition Research, School of Food and Nutritional Sciences, University College Cork, Cork, Ireland
}

Correspondence should be addressed to K D Cashman: k.cashman@ucc.ie

This paper forms part of a special series on 100 Years of Vitamin D. The guest editors for this section were Josef Köhrle, Susan Lanham-New and Martina Rauner

\begin{abstract}
Background: Internationally, concern has been repeatedly raised about the little notable progress in the collection, analysis and use of population micronutrient status and deficiency data globally. The need for representative status and intake data for vitamin D has been highlighted as a research priority for well over a decade.

Aim and methods: A narrative review which aims to provide a summary and assessment of vitamin D nutritional status data globally. This review divides the world into the Food and Agriculture Organisation's (FAO) major regions: the Americas, Europe, Oceania, Africa and Asia. Emphasis was placed on published data on the prevalence of serum 25 -hydroxyvitamin D $(25(\mathrm{OH}) \mathrm{D})<25 / 30$ and $<50 \mathrm{nmol} / \mathrm{L}$ (reflecting vitamin D deficiency and inadequacy, respectively) as well as vitamin $D$ intake, where possible from nationally representative surveys.

Results: Collating data from the limited number of available representative surveys from individual countries might suggest a relatively low overall prevalence of vitamin D deficiency in South America, Oceania and North America, whereas there is more moderate prevalence in Europe and Asia, and possibly Africa. Overall, the prevalence of serum 25(OH)D < 25/30 and $<50 \mathrm{nmol} / \mathrm{L}$ ranges from $\sim 5$ to $18 \%$ and 24 to $49 \%$, respectively, depending on FAO world region. Usual intakes of vitamin D can also vary by FAO world region, but in general, with a few exceptions, there are very high levels of inadequacy of vitamin D intake. Conclusions: While the burden of vitamin D deficiency and inadequacy varies by world regions and not just by UVB availability, the global burden overall translates into enormous numbers of individuals at risk.
Key Words
- vitamin D status
- usual vitamin D intake

- serum 25(OH)D

- national surveys

Endocrine Connections (2022) 11, e210282
\end{abstract}

\section{Introduction}

Vitamin D is set to very soon become a centenarian among the vitamin family. It has received an extraordinary level of increased research interest and effort in the last few decades, with PubMed showing the number of articles with the word 'vitamin D' in their title growing from one in 1922, 110 in 1952, 740 in 1982 to 5566 in 2020. Some of this huge expansion of recent research activity stems from the recognition of vitamin D's role not only in calcium and bone homeostasis but also in non-skeletal processes (1), all of which can be compromised by vitamin D deficiency.
Around a decade ago, we performed a detailed analysis of persistent knowledge gaps and research needs in vitamin D nutrition and public health, with particular emphasis on the prevention of vitamin D deficiency (2). We concluded that from among the wider suite of knowledge gaps, prioritising three research requirements, in particular, would enable the quantification of vitamin D deficiency in the population and would prevent that deficiency, and, by increasing vitamin $\mathrm{D}$ status across the distribution of vitamin $\mathrm{D}$ requirements, potentially prevent disease.

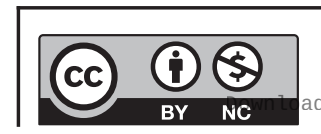

This work is licensed under a Creative Commons Attribution-NonCommercial 4.0 International License. ded from Bioscientifica.com at 04/26/2023 01:39:30PM 
These were to gather data on the distribution of (i) serum 25-hydroxyvitamin D $(25(\mathrm{OH}) \mathrm{D})$ concentrations and (ii) vitamin $\mathrm{D}$ intakes and food sources in nationally representative populations with appropriate consideration of sex, life-stage and ethnicity, and (iii) development of sustainable food-based strategies to bridge the gap between current and recommended intakes of vitamin D to minimise the prevalence of vitamin D deficiency (2).

There is consensus that serum or plasma $25(\mathrm{OH}) \mathrm{D}$ concentration should be used to assess vitamin $\mathrm{D}$ status because it reflects the contributions from both diet and dermal synthesis $(1,3)$. However, there has been considerable debate on the suggested thresholds of circulating 25(OH)D that define different degrees of low vitamin D status, such as deficiency, inadequacy and insufficiency (4). This can have a major bearing on the magnitude of the public health issue of low vitamin D status. In relation to vitamin $\mathrm{D}$ deficiency as it relates to nutritional rickets and osteomalacia, the majority of expert bodies have suggested serum 25(OH)D concentrations $<25$ or $<30 \mathrm{nmol} / \mathrm{L}$ are indicative of increased risk (1, 5, $6,7)$. There may be special considerations in relation to the serum $25(\mathrm{OH}) \mathrm{D}$ threshold(s) as applied to defining vitamin D deficiency in certain clinical patient groups. For example, the Endocrine Society Task Force on Vitamin D in the US (8), as part of their clinical practice guidelines, suggests that patients should be identified as vitamin D-deficient at a serum 25(OH)D cut-off level of $50 \mathrm{nmol} / \mathrm{L}$. From a more population health perspective, and as distinct from clinical care guidelines, several, but not all, expert bodies briefed with the development of dietary recommendations for vitamin $\mathrm{D}$, using musculoskeletal health outcomes as the primary basis, proposed $50 \mathrm{nmol} / \mathrm{L}$ as the concentration of serum $25(\mathrm{OH}) \mathrm{D}$ that would meet the physiological vitamin D requirement of nearly all of the general healthy population $(1,6,9,10)$. In this context, the suggested $50 \mathrm{nmol} / \mathrm{L}$ is not intended for vitamin $\mathrm{D}$ deficiency diagnostic purposes but used to underpin the vitamin D intake status relationship on which dietary recommendations are established (11).

Also within the framework of vitamin D recommendations, serum $25(\mathrm{OH}) \mathrm{D}$ concentrations greater than 30 but less than $50 \mathrm{nmol} / \mathrm{L}$ represent the risk of inadequacy/insufficiency for some in the population, whereas concentrations greater than $50 \mathrm{nmol} / \mathrm{L}$ represent sufficiency for nearly all $(1,9)$. Accordingly, in this review, the focus will largely be on the prevalence of serum $25(\mathrm{OH}) \mathrm{D}$ $<25$ or $30 \mathrm{nmol} / \mathrm{L}$, between $25 / 30$ and $50 \mathrm{nmol} / \mathrm{L}$ and $<50 \mathrm{nmol} / \mathrm{L}$. It will also focus, where possible, on the provision of prevalence data from studies that are nationally representative, although not unsurprisingly, such data will not be available for a sizeable majority of the globe, in which case data from other relevant studies will be presented. The prevalence estimates from nationally representative population-based surveys, especially if recent, provide the best snapshot of the burden of vitamin $\mathrm{D}$ deficiency and low vitamin D status within the general population. Furthermore, if the serum 25(OH)D data from these studies are standardised, as pioneered by the US National Institutes of Health-led Vitamin D Standardization Program (VDSP) in terms of limiting the impact of analytical method-related differences in serum $25(\mathrm{OH}) \mathrm{D}$ measurement (12), the estimates are even more trustworthy, and especially if these are intended to be compared across countries/regions. The importance of using standardised serum 25(OH)D values for comparisons of the prevalence of vitamin $\mathrm{D}$ deficiency is clearly illustrated by the data from two of the nationally representative surveys, both of which reside in a latitude band of $47-55^{\circ} \mathrm{N}$. In the case of the German Health Interview and Examination Survey for Adults (aged 18-79 years), the pre-standardisation prevalence estimate for serum $25(\mathrm{OH}) \mathrm{D}<30 \mathrm{nmol} / \mathrm{L}$ of $25.9 \%$ decreased after standardisation to $15.2 \%$ (13). For the Irish National Adult Nutrition Survey, the prevalence of deficiency in adults (aged 18-84 years) increased from 6.6 (pre-standardisation) to $12.3 \%$ after standardisation (14). Thus, the prevalence of vitamin D deficiency for these relatively cognate, predominantly white adult population samples, which were originally extremely disparate $(25.9 \%$ compared with $6.6 \%$ ), became close after standardisation (15.2\% compared with 12.3\%). Fully acknowledging that such standardisation was/is not feasible for all such surveys, the review will highlight, but not solely prioritise, such prevalence data. Beyond serum 25(OH)D data, nationally or regionally representative data on vitamin $\mathrm{D}$ intake in the population or in population subgroups may provide an additional source of information by which to determine the adequacy of vitamin D status in the population (15).

This narrative review will summarise our understanding of the present situation in relation to vitamin D nutritional status around the globe, based on data for circulating 25(OH)D and vitamin D intake, especially nationally representative data as per the first two priorities mentioned above. A review of vitamin D intake as well as status data, from nationally representative samples, where feasible, is particularly novel as the focus of reviews thus far has mainly been on vitamin D status in different world regions. The Food and Agriculture Organisation (FAO), for the purposes of food balance sheet data, uses five major regions within the world: the Americas, Europe, Oceania,

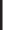

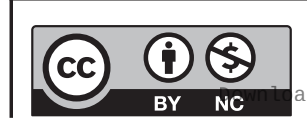


Africa and Asia (15). This may be a convenient approach when considering global differences in vitamin D status as well as dietary intake of the vitamin. In some cases, the FAO regions include more than one continent, such as North and South America, and can miss widely recognised world regions such as the Middle East owing to the fact that it straddles more than one FAO world region, but these will be flagged within the relevant sections below.

\section{Global differences in vitamin D status}

\section{The Americas}

In terms of the Americas, the United States of America (US) and Canada are the two countries within North America with the most comprehensive and representative data on vitamin D status. Data from the national nutrition surveys in the US (National Health and Nutrition Examination Survey 2011-2014; $\geq 1$ year, $n=16,180$ ) (16) and Canada (Canadian Health Measures Survey Cycles 1-3; $\geq 19$ years, $n=8351$ ) (17) suggest that 5.0 and $8.8 \%$ of the overall survey samples, respectively, had serum $25(\mathrm{OH}) \mathrm{D}$ concentrations $<30 \mathrm{nmol} / \mathrm{L}$ (Fig. 1), a cut-off representing an increased risk of vitamin D deficiency (1). The US survey used a standardised liquid chromatography with tandem mass spectrometry (LC-MS/MS) methodology for measurement of 25(OH)D, whereas the Canadian survey used an immunoassay-based method and the resulting $25(\mathrm{OH}) \mathrm{D}$ data were standardised via the VDSP protocols.
Both surveys report 25(OH)D data and/or prevalence estimates stratified by vitamin D supplement use among participants $(16,17)$. Notably, the two surveys also report the prevalence estimates stratified by race/ethnicity data which clearly highlight potential at-risk groups of low vitamin D status. The Canadian survey shows that the prevalence of serum $25(\mathrm{OH}) \mathrm{D}$ concentrations $<30 \mathrm{nmol} / \mathrm{L}$ in non-white participants was over three-fold higher than that of white participants (20.1\% vs 5.9\%, respectively; these estimates are not adjusted for seasonality) (17). The US survey presents prevalence estimates (adjusted for age and season) separately for non-Hispanic (N-H) black, N-H Asian and Hispanic (in the range 5.9-17.5\%; Fig. 1). Taking an average of these prevalence estimates to represent a 'non-white' grouping showed a nearly fivefold higher prevalence of serum $25(\mathrm{OH}) \mathrm{D}$ concentrations $<30 \mathrm{nmol} / \mathrm{L}$ than that of N-H white participants $(10.3 \%$ vs $2.1 \%$, respectively) (16). Even crude estimations based on the magnitude of total populations in these two North American countries, using census data from around the time of the surveys, together with the above-mentioned prevalence estimates, suggest something in the region of $\sim 2$ million adults in Canada and $\sim 15$ million individuals aged 1 year and older in the US are at increased risk of vitamin D deficiency. Within the US, based on race and ethnicity demographics, this would translate to $\sim 6.8$ million N-H blacks, $\sim 4.1$ million N-H whites, $\sim 3.2$ million Hispanics and $\sim 1.2$ million $\mathrm{N}-\mathrm{H}$ Asians with serum $25(\mathrm{OH}) \mathrm{D}$ concentrations $<30 \mathrm{nmol} / \mathrm{L}$.

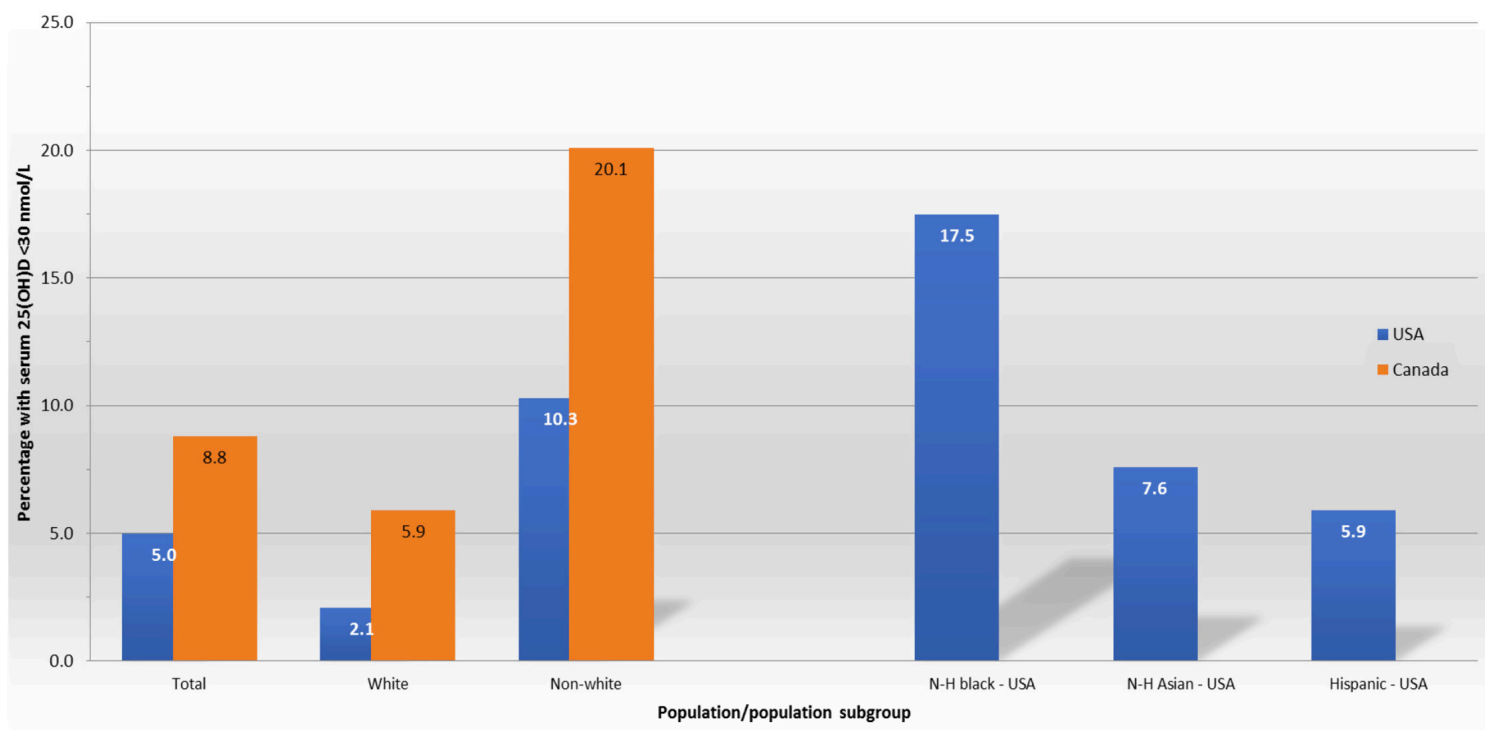

\section{Figure 1}

The prevalence of serum $25(\mathrm{OH}) \mathrm{D}<30 \mathrm{nmol} / \mathrm{L}$ in the national surveys in the USA and Canada and stratified by population racial group. In the case of the US survey, the 'non-white' prevalence for comparison with Canada is representing the average of the non-Hispanic ( $\mathrm{N}-\mathrm{H}$ ) black, $\mathrm{N}$ - $\mathrm{H}$ Asian and Hispanic groups (also shown separately).

https://ec.bioscientifica.com https://doi.org/10.1530/EC-21-0282
(C) 2022 The author Published by Bioscientifica Ltd
This work is licensed under a Creative Commons Attribution-NonCommercial 4.0 International License. ded from Bioscientifica.com at 04/26/2023 01:39:30PM 


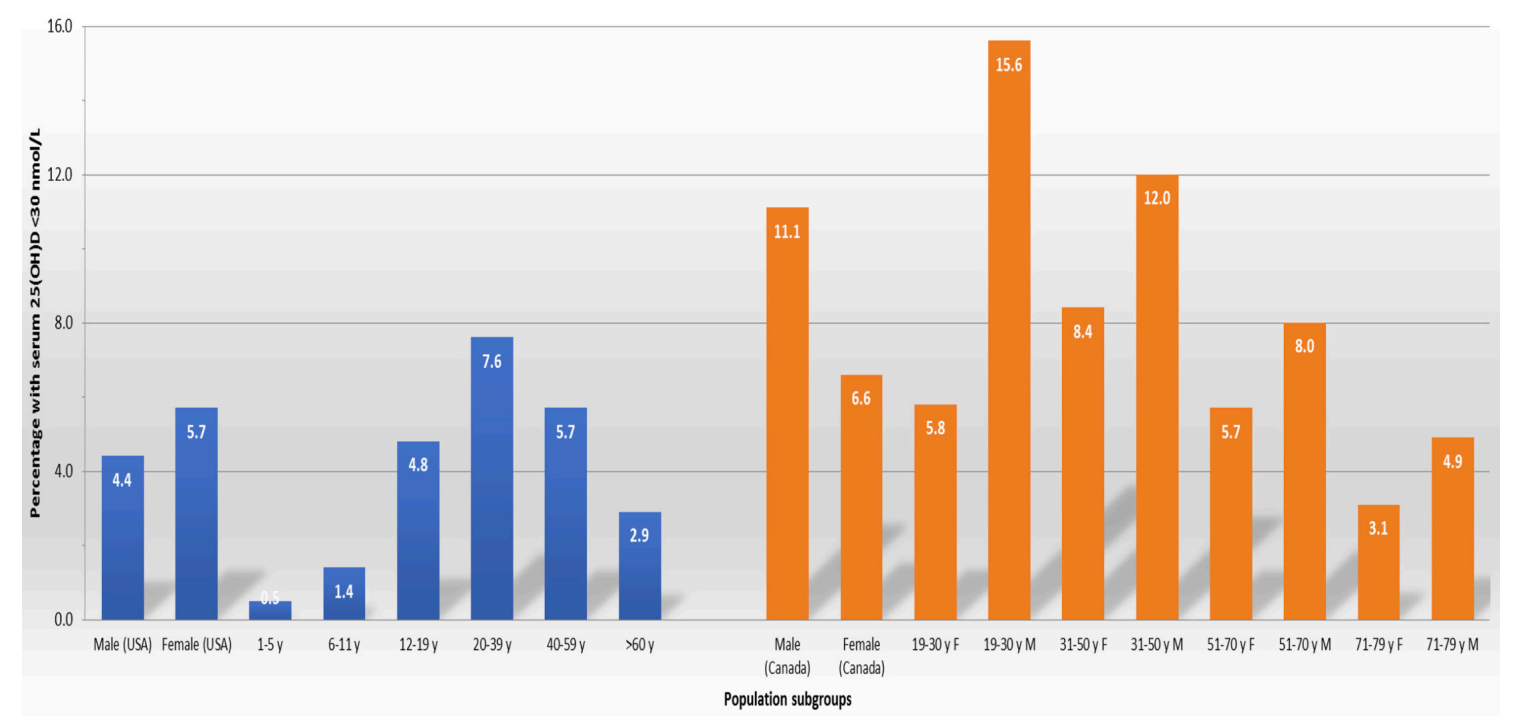

Figure 2

The prevalence of serum $25(\mathrm{OH}) \mathrm{D}<30 \mathrm{nmol} / \mathrm{L}$ in the national surveys in the USA and Canada stratified by sex and age grouping.

Both surveys also present prevalence estimates stratified by age group and by gender. Within the US survey, which included children, the prevalence of serum $25(\mathrm{OH}) \mathrm{D}$ concentrations $<30 \mathrm{nmol} / \mathrm{L}$ was very low in those aged $1-5$ and $6-11$ years ( 0.5 and $1.4 \%$, respectively) and rising to $\sim 5 \%$ in those aged $12-19$ years (16), while in both the US and Canadian surveys, the prevalence of serum $25(\mathrm{OH}) \mathrm{D}$ concentrations $<30 \mathrm{nmol} / \mathrm{L}$ was highest in young adults/adults (typically $\sim 8-11 \%$ in those aged $19 / 20-40 / 50$ years) and then declining in older adults $(\sim 3-4 \%)(16,17)$ (Fig. 2). While there were statistically significant gender differences in the prevalence of serum $25(\mathrm{OH}) \mathrm{D}$ concentrations $<30 \mathrm{nmol} / \mathrm{L}$ in both surveys, these were in opposite directions; males had a significantly lower prevalence compared to females $(4.4 \%$ vs $5.7 \%$, respectively) in the US survey but significantly higher prevalence $(11.1 \%$ vs $6.6 \%$, respectively) in the Canadian survey (Fig. 2).

The prevalence of serum 25(OH)D between 30 and 49 $\mathrm{nmol} / \mathrm{L}$ representing the risk of inadequacy of vitamin $\mathrm{D}$ status (1) was $18.3 \%$ overall $(11.8,35.8,29.1$ and $26.3 \%$ for $\mathrm{N}-\mathrm{H}$ white, N-H black, N-H Asian and Hispanic, respectively) for participants of the US survey (16). Data from the first two cycles of the Canadian Health Measures Survey (data not presented for latest report of cycles 1-3 (17)) suggest that $29.4 \%$ of the combined sample had serum $25(\mathrm{OH})$ D between 30 and $50 \mathrm{nmol} / \mathrm{L}$ (18). Again based on crude estimations of population demographics, this would translate into something in the region of $\sim 6.8$ million adults in Canada and $\sim 58$ million individuals aged $\geq 1$ year in the US at increased risk of inadequate vitamin $D$ status. Taking all concentrations of serum $25(\mathrm{OH}) \mathrm{D}<50 \mathrm{nmol} / \mathrm{L}$, as reflective of some degree of low vitamin D status, these crude estimates (which do not capture some population subgroup data) would suggest that something in the region of 82 million individuals in the US and Canada collectively are at risk.

Mexico has been considered a constituent country within North America but also Central America. The 2006 Mexican National Health and Nutrition Survey (ENSANUT) showed in a nationally representative sample of preschool children, school children, adolescents and adults prevalence estimates of serum $25(\mathrm{OH}) \mathrm{D}<50 \mathrm{nmol} / \mathrm{L}$ of $24,10,8$, and $10 \%$, respectively (19). The prevalence of $25(\mathrm{OH}) \mathrm{D}<20 \mathrm{nmol} / \mathrm{L}$ was less than $1 \%$ for all groups (19). More recent data have been published for some of these sub-groups of the Mexican population arising from the ENSANUT 2012 survey (which used a chemiluminescent microparticle immunoassay for measurement of $25(\mathrm{OH}) \mathrm{D}$, did not adjust for seasonality and did not include information on vitamin D supplement use). For example, the prevalence of serum $25(\mathrm{OH}) \mathrm{D}<50 \mathrm{nmol} / \mathrm{L}$ was $25.9 \%$ in pre-schoolers ( $1-4$ years; $n=1325$ ) (20), 36.6\% in schoolage children ( $5-11$ years; $n=1370$ ) (20) and $37.2 \%$ in women of reproductive age $(n=3260)$ (21). A cross-sectional analysis of the third (2012) wave from the Mexican Health and Aging Study, a prospective cohort with a representative sample of community-dwelling Mexican older adults ( $\geq 50$ years), showed that the prevalence of serum $25(\mathrm{OH})<50 \mathrm{nmol} / \mathrm{L}$ was $36.8 \%$ in these older adults (mean age, 69.5 years; $n=1128$ ) (22).

The US, Canada and Mexico account for $\sim 85 \%$ of the total population of North America, incorporating 
Central America, the remaining $15 \%$ are accounted for by 20 other countries. In general, nationally representative data on serum 25(OH)D are not available for these countries. Data from a cross-sectional analysis of serum 25(OH)D concentrations in children (aged 7-12 years; $n=223)$ and their parents $(n=492)$ sampled from the capital cities of nine Mesoamerican countries (in the period 2011-2013) (23) provide a snapshot of vitamin D status in the remainder of the North American region. Acknowledging that the samples were not representative of the underlying populations, the prevalence of serum $25(\mathrm{OH}) \mathrm{D}$ concentrations $<50 \mathrm{nmol} / \mathrm{L}$ ranged from 1.6 to $9.4 \%$ in adults and 0 to $11.5 \%$ in children from Guatemala, El Salvador, Dominican Republic, Honduras, Nicaragua, Panama, Costa Rica and Belize. Only one person out of the whole sample had a serum $25(\mathrm{OH}) \mathrm{D}$ concentration below $30 \mathrm{nmol} / \mathrm{L}$ (23). It is also worth noting that the seven constituent countries within Central America were included in this study.

While some of the constituent countries within South America have no published data on vitamin D status, and very few have nationally representative data on serum $25(\mathrm{OH}) \mathrm{D}$, several have data available from individual published studies. Two reviews have collated the available data and presented same on an individual country basis $(24,25)$. Caution is needed in drawing conclusions about population vitamin $\mathrm{D}$ status based on individual studies as they are not representative, and in many cases, these have relatively small sample sizes. Other study design parameters as well as the method of serum $25(\mathrm{OH}) \mathrm{D}$ analysis also differed, all of which contributed to variable estimates of the prevalence of vitamin D deficiency or inadequacy, in some cases, even within a country. The Latin Americaspecific review by Brito et al. (24) in 2013, together with the more global review by Palacious and Gonzalez (25) in 2014, collectively provided estimates of vitamin D status for one or more population subgroups in Colombia, Ecuador, Brazil, Chile and Argentina. In summary, the prevalence of serum 25( $\mathrm{OH}) \mathrm{D}<25 \mathrm{nmol} / \mathrm{L}$ in Argentinean adults and elderly were in the range $0-16$ and $0-14 \%$, respectively, whereas $15-55$ and $15-73 \%$ of adults and elderly had serum $25(\mathrm{OH}) \mathrm{D}$ concentrations between 25 and $50 \mathrm{nmol} / \mathrm{L}$. The 2004/05 Argentinean National Health Survey reported a prevalence of serum $25(\mathrm{OH}) \mathrm{D}<25 \mathrm{nmol} / \mathrm{L}$ as well as between 25 and 50 $\mathrm{nmol} / \mathrm{L}$ in a subsample of young children (6-23 months of age) from the Patagonia region as 3 and $24 \%$, respectively. The prevalence of serum $25(\mathrm{OH}) \mathrm{D}<40 \mathrm{nmol} / \mathrm{L}$ among the elderly in Ecuador was in the range of $9-19 \%$. The prevalence of serum $25(\mathrm{OH}) \mathrm{D}<23 / 25 \mathrm{nmol} / \mathrm{L}$ in adult and elderly in Brazil ranged from 2 to $16 \%$, while $9-10$ and $50-73 \%$ of Brazilian children/adolescents and adult/ elderly, respectively, had serum $25(\mathrm{OH}) \mathrm{D}$ concentrations in the range $25-50 \mathrm{nmol} / \mathrm{L}$. The data presented by both reviews in relation to Chilean females were from the period around 2001-2007 $(24,25)$, which has now been superseded by some preliminary nationally representative data from the Chilean National Health Survey 2016-2017, which included adult ( $\geq 18$ years; $n=1245$ ) and older adult ( $\geq 65$ years; $n=686$ ) females (26). The prevalence of serum $25(\mathrm{OH}) \mathrm{D}<30 \mathrm{nmol} / \mathrm{L}$ was 16.4 and $26.4 \%$ for the adult and older adult Chilean females, respectively, and 51.6 and $64.9 \%$ had serum $25(\mathrm{OH}) \mathrm{D}$ concentrations $<50 \mathrm{nmol} / \mathrm{L}$, respectively. Analysis on the basis of Chilean's territories showed that the population from the North exhibits much higher serum 25(OH)D concentrations compared to those of the South (26). Likewise, data presented by both reviews in relation to Colombian children were from $2010(24,25)$, which has now been superseded by prevalence estimates from the 2015 Colombian National Nutrition Survey (27). The prevalence of serum 25(OH)D (using an immunoassay) $<30 \mathrm{nmol} / \mathrm{L}$ was 3.1, 1.9, 2.4, 3.0, 6.7 and 3.7\% for toddlers $(n=2104)$, pre-schoolers $(n=6813)$, school children ( $n=16,454)$, adolescents $(n=6470)$, pregnant women $(n=1262)$ and non-pregnant women aged 18-49 years $(n=7170)$, respectively and 39.4, 25.8, 19.4, 17.4, 26.6 and $20.1 \%$ with serum $25(\mathrm{OH}) \mathrm{D}$ between 30 and $50 \mathrm{nmol} / \mathrm{L}$, respectively (27).

\section{Europe}

In terms of Europe, as evidenced in a number of reviews of vitamin D status globally $(25,28,29)$, there are a considerable number of individual studies available from across the continent. However, a cautionary note needs to be struck again in relation to the representativeness of these individual studies and the importance of nationally or sub-nationally representative data. As part of the European Commission-funded ODIN vitamin D project (30), 14 nationally or regionally representative studies were gathered and their existing serum $25(\mathrm{OH}) \mathrm{D}$ data (based on a wide collection of analytical methods) were standardised as per VDSP protocols. While the project prioritised nationally representative nutrition surveys and was able to include such from Ireland, the UK and Germany, several member states in Europe do not have such nationally representative surveys. Thus, in the absence of such data, well-curated samples from regionally representative health surveys were used, as they can also achieve some degree of population coverage (30). The prevalence of vitamin D deficiency and inadequacy (based on data of VDSP standardised serum

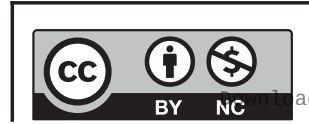

This work is licensed under a Creative Commons Attribution-NonCommercial 4.0 International License. ded from Bioscientifica.com at 04/26/2023 01:39:30PM 


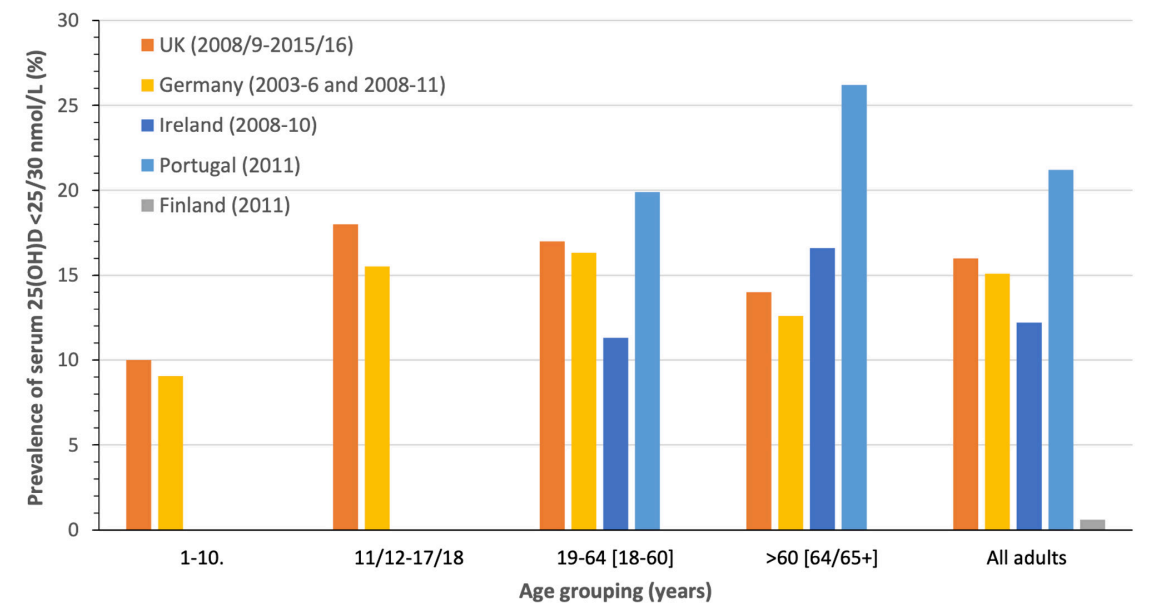

\section{Figure 3}

The prevalence of serum 25(OH)D $<25(\mathrm{UK}) / 30$ $\mathrm{nmol} / \mathrm{L}$ in national surveys in Germany, the UK, Finland and Portugal stratified by age grouping (ranges in brackets are the German and Portugal equivalent groupings, respectively). Estimates averaged across sex and two age groupings in some cases for comparability.
$25(\mathrm{OH}) \mathrm{D}<30$ and $<50 \mathrm{nmol} / \mathrm{L}$, respectively), when these representative population samples in Europe were pooled ( $n=55,844)$, was 13 and $40.4 \%$, respectively (30). It should be noted that these are whole-population estimates and intended to provide some insight into the prevalence of vitamin D deficiency and inadequacy for the European region, which could then be compared with other world regions, particularly North America. It is important to stress that prevalence estimates can vary by member state within Europe and also by age grouping. For example, data from the four nationally representative samples within the project, as well as more recently from Portugal (31) (based on immunoassay data), show that the prevalence of serum $25(\mathrm{OH}) \mathrm{D}<30 \mathrm{nmol} / \mathrm{L}$ varied from as low as $\sim 1 \%$ to as high as $21 \%$ (see Fig. 3). The yearly estimates for four of the five representative samples were not adjusted for seasonality, but estimates based on extended winter and extended summer were also reported for these. The analysis within the ODIN project also showed that the prevalence of vitamin $\mathrm{D}$ deficiency by age group, and irrespective of latitude of study populations, suggests that teenagers may have higher risk on average. The range of deficiency in the various teenage study populations (aged 15-18 years) was $12-40 \%$, whereas childhood samples (aged 1-6 and 7-14 years), older adult samples ( $>61$ years) and adult samples were 4-7, 1-8 and 9-24\%, respectively (30). In general, sex differences in prevalence of serum $25(\mathrm{OH}) \mathrm{D}<30 \mathrm{nmol} / \mathrm{L}$ within the entire collection of studies were not evident (13.1\% compared with $12.9 \%$, on average, for males and females, respectively) (30). Such comparisons need to be interpreted cautiously because differences in the latitude of sample population, ethnic mix and season of blood sampling differed for these populations. The prevalence estimates within the ODIN project were not stratified by vitamin D supplement use.
A concerning finding within the ODIN project, and which aligns with that reported from the North American surveys, was that dark-skinned ethnic groups within Europe are also worryingly at much increased risk of vitamin D deficiency compared to their white counterparts (prevalence $<30 \mathrm{nmol} / \mathrm{L}$ in the range 28-65\%, depending on the country and the ethnic group) $(30,32)$. Within the Finnish representative Migrant Health and Wellbeing Study (Maamu) sample, the prevalence of serum 25(OH)D < $30 \mathrm{nmol} / \mathrm{L}$ was 4.5, 28.0 and $50.4 \%$ for white Russianspeaking $(n=446)$, Somali $(n=364)$ and Kurdish immigrant subgroups $(n=500)$, respectively. Likewise, although with very limited numbers, within the representative National Diet and Nutrition Survey (NDNS) in the United Kingdom (UK), the prevalence of serum $25(\mathrm{OH}) \mathrm{D}<30 \mathrm{nmol} / \mathrm{L}$ was 35.7 and $59.6 \%$ in black $(n=28)$ and Asian participants $(n=52)$, respectively, compared with $19.6 \%$ in white participants $(n=1359)$ (30). We had stressed the need for caution in terms of the interpretation of the UK data due to the fact that the numbers were low. Interestingly, recent findings in relation to the prevalence of vitamin D deficiency among participants in the UK Biobank cohort (33), a population-based cohort of 500,000 participants recruited in the UK between 2006 and 2010 echoed these earlier findings. Acknowledging that the UK biobank is not fully representative of the sampling population, the prevalence of serum $25(\mathrm{OH}) \mathrm{D}<25 \mathrm{nmol} / \mathrm{L}$ in adult participants of South Asian $(n=5936)$ and black ethnicity $(n=5054)$ was much higher than that of Caucasian ( $n=331,849$ ) (57.3 and $36.3 \%$ vs $11.7 \%$, respectively) (33).

Notwithstanding the important ethnic differences and age-group differences, even a crude estimation based on the magnitude of populations in the Europe Union coupled with the above population-wide prevalence estimate from the ODIN project, suggest something in the region of

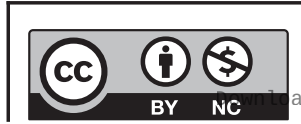

This work is licensed under a Creative Commons Attribution-NonCommercial 4.0 International License. ded from Bioscientifica.com at 04/26/2023 01:39:30PM 
66 million individuals in the European Union member states are at risk of vitamin D deficiency.

It is also important to stress that while it was feasible to include data from numerous European countries, for several others, data were not available. For example, a systematic review from the ODIN project highlighted that many countries in the Central and Eastern European region, including Albania, Belarus, Bosnia and Herzegovina, Bulgaria, Latvia, Macedonia, Moldova, Montenegro and Slovakia had no published data on vitamin D status (34). A 2018 review of the current status in relation to national nutrition surveys in the 53 countries of the WHO European region highlights the fact that less than two-thirds have nationally representative diet surveys, and again, the main availability gaps lie in Central and Eastern European countries (35). The author of the present review conducted individual PubMed searches of published literature arising from those same nationally representative dietary surveys (35) to establish if any of these had reported serum/plasma 25(OH)D data and thus widening the information on European countries beyond those included in the ODIN project. These searches highlighted that the vast majority do not have serum/ plasma $25(\mathrm{OH}) \mathrm{D}$ data available, which was our finding at the time of gathering national samples for the ODIN project around 2011. The searches did however highlight that as an extension to the national dietary survey 'SI. Menu (2017/18)' in Slovenia, the national Nutrihealth Study was conducted on a representative sample of 125 adults (18-64 years) and 155 elderly (65-74 years) subjects, enrolled in the study in different seasons. Altogether, $24.9 \%$ of the adults and $23.5 \%$ of the elderly were found to have serum $25(\mathrm{OH}) \mathrm{D}<30 \mathrm{nmol} / \mathrm{L}$, while 58.2 and $62.9 \%$, respectively, had serum $25(\mathrm{OH}) \mathrm{D}$ concentrations $<50 \mathrm{nmol} / \mathrm{L}$ (36).

\section{Oceania}

Recent data have been reported on the prevalence of vitamin $\mathrm{D}$ deficiency and inadequacy in nationally representative samples of Australian adults (37) and Australian Aboriginal and Torres Strait Islander adults (38). Standardised serum 25(OH)D data (measured via LC-MS/MS) for adults aged $\geq 25$ years $(n=5034)$, who participated in the 2011-2013 Australian Health Survey, confirms the prevalence of serum $25(\mathrm{OH}) \mathrm{D}<30$ and $<50 \mathrm{nmol} / \mathrm{L}$ as 4.5 and $20.1 \%$, respectively. Again with the use of census data, these estimates would translate into approximately 0.8 and 3.3 million Australian adults aged $\geq 25$ years at risk of vitamin D deficiency and inadequacy, respectively.
The prevalence estimates were highest in the 25-24 and $35-33$ years age categories and lowest among the 55-64 and 65-74 years age categories (37). The prevalence of serum $25(\mathrm{OH}) \mathrm{D}<30 \mathrm{nmol} / \mathrm{L}$ was $4.1 \%$ in all men and $4.9 \%$ in all women (37). The prevalence estimates also varied by state/territory with the lowest $(0.6 \%)$ in the Australian Capital Territory and the highest prevalence of serum $25(\mathrm{OH}) \mathrm{D}<30 \mathrm{nmol} / \mathrm{L}$ in the Northern Territory (7.1\%).

Use of standardised serum $25(\mathrm{OH}) \mathrm{D}$ data from the 2012-2013 Australian Aboriginal and Torres Strait Islander Health Survey of adults aged $\geq 18$ years $(n=3250)$ shows a prevalence of 4.7 and $27.0 \%$ using the $<30$ and $<50 \mathrm{nmol} / \mathrm{L}$ thresholds, respectively, in this nationally representative sample (38). Again, the prevalence of serum $25(\mathrm{OH}) \mathrm{D}<30$ $\mathrm{nmol} / \mathrm{L}$ was similar in men and women $(5.0$ and $4.5 \%$, respectively). Seventeen percent and $32 \%$ of adolescents (12-17 years, $n=692)$ and young adults (18-24 years, $n=400$ ), who participated in the nationally representative 2011-2013 Australian Health Survey had serum 25(OH)D concentrations (measured via LC-MS/MS) $<50 \mathrm{nmol} / \mathrm{L}$ (39). In the overall sample of 12 - to 24 -year-old, the prevalence of inadequacy was $29 \%$ in males and $23 \%$ in females (39).

The yearly estimates for all three representative samples were not adjusted for seasonality, but estimates based on season were also reported $(37,38,39)$, as were estimates based on vitamin D supplement use or not for the Australian adults (37) but not the other two samples $(38,39)$.

Data from the 2002 Children's National Survey in New Zealand has shown that 7.5 and $48.5 \%$ of children (aged 5-15 years) of the 'New Zealand European and other group' ethnic group $(n=468)$ had serum $25(\mathrm{OH}) \mathrm{D}$ (measured by immunoassay) $<30$ and $<50 \mathrm{nmol} / \mathrm{L}$, respectively (40). Data from a national sample of New Zealanders aged 15 years and older who participated in the 2008/09 New Zealand Adult Nutrition Survey $(n=3099)$ suggest that 4.9 and $27.1 \%$ had serum 25(OH)D (measured via LC-MS/MS and standardised for month) $<25$ and $25-49.9 \mathrm{nmol} / \mathrm{L}$, respectively. There was no significant difference in prevalence between males and females. By ethnic grouping, 6 and 10.5\% of Maori and Pacific individuals, respectively, had serum 25(OH)D $<25$ $\mathrm{nmol} / \mathrm{L}$, whereas the equivalent prevalence estimates using $25-49.9 \mathrm{nmol} / \mathrm{L}$ were 33.7 and $46.6 \%$, respectively (41). The surveys did not examine estimates stratified by vitamin D supplement use.

Data on women of child-bearing age from both major ethnic groups, indigenous Fijians and Fijian Indians, who participated in the 2004 Fiji National Nutrition Survey $(n=511)$ suggest that 3 and $11 \%$ of the overall sample had serum $25(\mathrm{OH}) \mathrm{D}$ concentrations (measured by 
immunoassay) $<37.5$ and $<50 \mathrm{nmol} / \mathrm{L}$, respectively (42). By ethnic grouping, 2 and 5\% of indigenous Fijian and Fijian Indian women had serum $25(\mathrm{OH}) \mathrm{D}<37.5 \mathrm{nmol} / \mathrm{L}$, respectively, whereas the equivalent prevalence estimates at $<50 \mathrm{nmol} / \mathrm{L}$ were $7 \%$ and $21 \%$, respectively (42). The sampling period was from May to September so winter-only data. A 2019 review of vitamin D deficiency in low-middle income countries (LMICs) has highlighted that several other Oceanic countries (Kiribati, Papua New Guinea, Samoa, Solomon Islands and Vanuatu) had no published studies with vitamin D data suitable for inclusion (43).

\section{Africa}

The reviews on vitamin D status globally $(25,28,29)$, as well as in LMICs (43), present vitamin D deficiency/ insufficiency prevalence data for some of Africa's 54 countries. For the most part, this data come from individual studies, owing to a lack of representative studies. Moreover, a significant number $(n=28)$ of individual countries in Africa were found to have no suitable serum $25(\mathrm{OH}) \mathrm{D}$ data for inclusion in the systematic review of vitamin D status in LMICs (43). A very recent systematic review and meta-analysis of the prevalence of vitamin $\mathrm{D}$ deficiency in Africa included 129 studies (with 21,474 participants) from 23 African countries (44). Egypt $(n=31)$, Nigeria $(n=21$ studies) and South Africa ( $n=19$ studies) had the highest number of eligible studies, 11 countries had 1 study, 4 countries had 2 studies and 5 other African countries had between 3 and 6 studies. Again, over half of the African studies $(n=31)$ did not have studies that measured vitamin D status (44). Using data from 119 of the studies in metaanalyses yielded pooled prevalence estimates of $18.5 \%$ for serum $25(\mathrm{OH}) \mathrm{D}<30 \mathrm{nmol} / \mathrm{L}$ and $34.2 \%$ for serum $25(\mathrm{OH}) \mathrm{D}$ $<50 \mathrm{nmol} / \mathrm{L}$. While 18 studies individually investigated seasonality in $25(\mathrm{OH}) \mathrm{D}$ concentrations, the pooled estimates were based on the entire collection of studies. The analyses also showed that most studies that reported low 25(OH)D concentrations were from northern African countries and South Africa as compared with sub-Saharan Africa, populations in urban areas had lower vitamin D status than those in rural areas, and in six out of nine studies in which a comparison by sex was provided, men had higher mean concentrations than women (44). An invited commentary piece on the systematic review draws attention to the fact that while it has long been believed that Africa was largely spared from severe vitamin D deficiency as a consequence of high sunshine availability for much of the continent, the findings of the systematic review suggest a potentially higher prevalence of serum
$25(\mathrm{OH}) \mathrm{D}<30 \mathrm{nmol} / \mathrm{L}$ than in Europe (18.5 vs 13\%, respectively) (45). However, importantly, the commentary also points to some key limitations, including the fact that the sample is not representative of the African population and overrepresents North African countries and South Africa, with no data on many African countries (45), which are likely to impact, to some unknown extent, on the reported prevalence estimates.

\section{Asia}

Asia is the world's most populated continent as well as having the greatest landmass, and accordingly, it is important to assess data on vitamin D status in countries constituent to its sub-regions of North, Central, West, South and South-East Asia. The reviews on vitamin D status globally $(25,28,29)$, as well as in LMICs (43), present vitamin D deficiency/insufficiency prevalence data for some of the countries within these regions, but in many cases, these are based on data from individual studies, owing to a lack of representative data. For Central Asia, based on the findings of the 2019 systematic review of LMICs (43), together with a search of those countries that were not included in that exercise, highlight that all but Kazakhstan did not have published data on serum 25(OH)D. A cross-sectional study of adults $(n=1347)$, covering six regions of Kazakhstan, showed that the prevalence of serum $25(\mathrm{OH}) \mathrm{D}<25 \mathrm{nmol} / \mathrm{L}$ was $27.5 \%$ overall, being $34.6 \%$ in females and only $16.7 \%$ in males, and was significantly higher in Asians (33.2\%) compared to Caucasians (6.7\%) (46). The prevalence of serum $25(\mathrm{OH}) \mathrm{D}$ between 25 and $50 \mathrm{nmol} / \mathrm{L}$ was $42.4 \%$ overall (46).

There were some vitamin D status data available for the majority of countries in Western Asia. Many of these countries are also considered as being within the Middle East region. A recent position statement of the European Calcified Tissue Society on current vitamin D status in European and Middle East countries suggest that while data are highly variable, in general, vitamin $\mathrm{D}$ deficiency (serum $25(\mathrm{OH}) \mathrm{D}<30 \mathrm{nmol} / \mathrm{L}$ ) is much more prevalent in the Middle East (highly variable generally in the range 30-90\%) than in Northern (range 0.4-8.4\%) and Western Europe (range 4.6-30.7\%) (47). The systematic review of vitamin D status in LMICs used a public health index of $>20 \%$ prevalence of serum $25(\mathrm{OH}) \mathrm{D}<25 / 30 \mathrm{nmol} / \mathrm{L}$ in the entire population and/or in one or more subsets of the population considered especially at risk to identify countries and regions with excess burden of vitamin D deficiency (43). It referred to such countries as 'hot spots', or as 'possible hot spot' countries, if data were based on

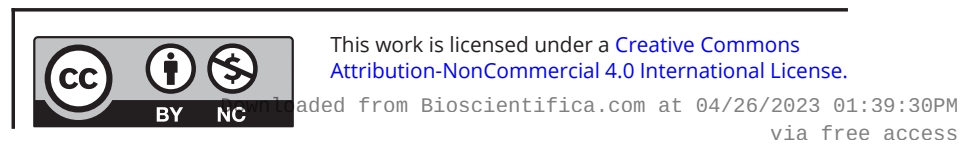


only one study. Three of the LMICs within the Western Asia/Middle-East region were such 'possible hot spot' countries; the West Bank and Gaza (56-70\% of women of child-bearing age having serum $25(\mathrm{OH}) \mathrm{D}<27.5 \mathrm{nmol} / \mathrm{L})$, Yemen $(61 \%$ of girls with serum $25(\mathrm{OH}) \mathrm{D}<30 \mathrm{nmol} / \mathrm{L})$ and Syria $(58.2 \%$ of adults with serum $25(\mathrm{OH}) \mathrm{D}<25 \mathrm{nmol} / \mathrm{L})$ (43). Palacious and Gonzalez (25) in their global review of vitamin D status in 2014 also highlighted the Middle East as having a high burden of vitamin $\mathrm{D}$ deficiency.

There were also some vitamin D status data available for the majority of countries in Eastern Asia. Mongolia is an example of the above-mentioned 'hot spot' LMICs (43). The 4th National Nutrition Survey in 2010 showed that the prevalence of serum $25(\mathrm{OH}) \mathrm{D}<18 \mathrm{nmol} / \mathrm{L}$ was $21.8 \%$ in children under 5 years of age and 30\% in non-pregnant women (48). The 5th National Nutrition Survey in 2016-2017 showed that the prevalence of serum 25(OH)D (measured by immunoassay) $<50 \mathrm{nmol} / \mathrm{L}$ was $61 \%$ in infants, $75.4 \%$ of pregnant women and $40.4 \%$ of men aged $15-49$ years (49). The 2010 survey sampled during July to August, whereas the 2016-2017 sampled during September to November.

While nationally representative data on vitamin D status exists for South Korea, there is a lack of published data on vitamin D status for North Korea. Data from adults in the Korean National Health and Nutrition Examination Survey (KNHANES) 2008-2014 $(n=46,405)$ showed that 9.4 and $57.5 \%$ had serum $25(\mathrm{OH}) \mathrm{D}$ concentrations (measured by immunoassay) $<25$ and between 25 and $50 \mathrm{nmol} / \mathrm{L}$, respectively (50). The serum 25(OH)D data were not adjusted for season, and data on supplement use were not collected. A temporal analysis over the period from 2008 to 2014 has provided evidence that vitamin D status in South Koreans deteriorated, with the prevalence of serum $25(\mathrm{OH}) \mathrm{D}<50 \mathrm{nmol} / \mathrm{L}$ of 51.8 and $68.2 \%$ of males and females, respectively, in 2008, but rose to 75.2 and $82.5 \%$, respectively, in 2014 (51). While some variation from year to year was evident, overall, there were significant decreases in mean serum $25(\mathrm{OH}) \mathrm{D}$ concentrations in both males $(-1.2 \mathrm{nmol} / \mathrm{L}$ per year, on average) and females ( $-0.7 \mathrm{nmol} / \mathrm{L}$ per year, on average) over the period 2008 to 2014. The reason for this trend, which seems at odds with the reverse trend observed in some western countries, was unclear, but the authors speculated that they may relate to changes in lifestyle and environment (e.g. increase in urban population, decrease in the number of people engaged in outdoor occupations, air pollution) which are associated with sunlight exposure (51). It is worth noting that during the 7-year period, serum 25(OH)D samples were measured in the same central testing centre, and thus, method- related differences are unlikely the principal reason for the downward trend observed.

Zhang et al. reviewed vitamin $\mathrm{D}$ status data for Mainland China, published during 2000 to 2012 (52). While estimates were highly variable, as constituent individual studies differed by location, assay and season of sampling, the average prevalence of serum $25(\mathrm{OH}) \mathrm{D}$ $<25 \mathrm{nmol} / \mathrm{L}$, using tabulated estimates provided within the review for children, adults and elderly, was $\sim 30 \%$. More recently, nationally representative data have been published, at least for some population subgroups. A cross-sectional analysis of healthy adults aged 60 years or older who participated in the nationally representative 2010-2013 China National Nutrition and Health Survey (CNNHS) showed that 7.8 and $26.3 \%$ of elderly men ( $n=2948$ ) had serum $25(\mathrm{OH}) \mathrm{D}$ (measured by immunoassay) $<30$ and between 30 and $50 \mathrm{nmol} / \mathrm{L}$, respectively, and 12 and 32\%, respectively, for elderly women $(n=3066)$ (53). The estimates stratified by season and vitamin D supplement use were also reported. The 2011 wave of the Chinese Longitudinal Healthy Longevity Survey, a nationally representative survey of older adults in which two-thirds of the participants ( $n=2180$, sampled from May to September) were aged 80 years and older, showed that 30.6 and $70.3 \%$ had serum $25(\mathrm{OH}) \mathrm{D}$ (measured by immunoassay) $<30$ and $<50 \mathrm{nmol} / \mathrm{L}$, respectively (54). The survey did not have data on supplement use. The prevalence of serum $25(\mathrm{OH}) \mathrm{D}<25$ and 25-50 nmol/L in children and adolescent participants $(n=14,473)$ in the 2010-2012 CNNHS was 7.2 and $46.0 \%$, respectively (55). The prevalence of $25(\mathrm{OH}) \mathrm{D}$ (measured by immunoassay) $<25 \mathrm{nmol} / \mathrm{L}$ in children aged 6-11, 12-14 and 15-17 years was 5.6, 8.8 and 8.7\%, respectively (55). The estimates stratified by season were also reported. Vitamin D supplement use was only $1.4 \%$, and thus, data were not presented by supplement use.

Nationally representative data for Japan is lacking; however, data from the Furukawa Nutrition and Health Study of factory workers in Japan (aged 18-69 years; $n=1790$, predominantly males) showed that $40.8 \%$ had serum $25(\mathrm{OH}) \mathrm{D}$ (measured by competitive proteinbinding assay) $<50 \mathrm{nmol} / \mathrm{L}$ (56). The serum was collected without regard to specific seasons. A primary care cohort of 1470 postmenopausal Japanese women (sampled in April and May) was reported as having 49.6\% with $25(\mathrm{OH}) \mathrm{D}$ (measured by competitive protein-binding assay) $<50 \mathrm{nmol} / \mathrm{L}(57)$.

For Southern Asia, based on the findings of the systematic review of LMICs, a number of the countries were considered 'hot spot' countries with excess burden of vitamin D deficiency (Pakistan $(25 \%<20 \mathrm{nmol} / \mathrm{L}$ and 
$61-65 \%<25 \mathrm{nmol} / \mathrm{L})$, Afghanistan $(45-65 \%<20 \mathrm{nmol} / \mathrm{L})$ and India (31-65\% $<25 \mathrm{nmol} / \mathrm{L})$, depending on population subgroup) (43). The prevalence of serum 25(OH)D (measured by immunoassay) $<25$ and $26-50 \mathrm{nmol} / \mathrm{L}$ in adult participants (aged 19-65 years; $n=1111$ ) of the 2013-14 National Food and Nutrition Surveillance Programme in Iran was 63.0 and $27.3 \%$, respectively in winter, and 26.6 and $43.2 \%$, respectively in summer (58). Data from children (aged 5-18 years; $n=667$ ) within the National Food and Nutrition Surveillance Programme during mid-winter 2013 (January and February) shows that 56 and 37.2\% had serum $25(\mathrm{OH}) \mathrm{D}$ (measured by immunoassay) $<25 \%$ and $25-50$ $\mathrm{nmol} / \mathrm{L}$, respectively (59). The prevalence of serum 25(OH)D $<25 / 30 \mathrm{nmol} / \mathrm{L}$ in Nepalese pregnant/lactating women and young children was $\sim 14 \%$, and $12-38.9 \%$ of nonpregnant Bangladeshi women were deficient, depending on socioeconomic status and veiled or unveiled. However, in both Nepal and Bangladesh, the prevalence of serum $25(\mathrm{OH}) \mathrm{D}<30 \mathrm{nmol} / \mathrm{L}$ in infants was much lower (0.6 and $6 \%$, respectively). There was a low prevalence of vitamin $\mathrm{D}$ deficiency in Sri Lankan children and adults (0-6.3\%) (43), and there are no data for the Maldives.

For South East Asia, the systematic review of LMICs highlighted the lack of 25(OH)D data for some countries (Lao, Myanmar, Timor-Leste) while pointed to a low prevalence of vitamin D deficiency in Indonesian children and adults as well as Cambodian women and children and was absent in Filipino postmenopausal women (43). The prevalence of vitamin D deficiency in Vietnam was variable, at $11.2-20.6 \%$ in children and $17.3 \%$ in women (43).

Data from the Fourth National Health Survey (20082009) in Thailand (adults 15-98 years; $n=2641$, sampled between August to March) showed that only 5.7\% overall had serum $25(\mathrm{OH}) \mathrm{D}$ concentrations (measured by LC-MS/MS) $<50 \mathrm{nmol} / \mathrm{L}$, although the estimate varied across geographic region, highest in Bangkok (2.8-14.3\%) (60). In Malaysia, the prevalence of serum 25(OH)D (measured by immunoassay) $<50 \mathrm{nmol} / \mathrm{L}$ in children (aged 4-12 years) participating in the Nutrition Survey of Malaysian Children was $47.5 \%$, higher in rural than urban areas and higher in girls than boys (61). Data from 12-yearold participants in the Malaysian Health and Adolescents Longitudinal Research Team study (MyHeARTs) ( $n=1361$, sampled between March and May) showed that 1.5, 77.4 and $13.7 \%$ had serum $25(\mathrm{OH}) \mathrm{D}$ concentrations (measured by immunoassay) $<12.5,12.5-37.5$ and $37.5-50 \mathrm{nmol} / \mathrm{L}$, respectively (62). Again, females had higher prevalence of low vitamin D status compared to males and higher in urban than rural areas (62).
The 2010/2011 South East Asian Nutrition Surveys (SEANUTS) were conducted in Indonesia, Malaysia, Thailand and Vietnam in country representative samples of children aged 0.5 to 12 years, and a subsample $(n=2016)$ had serum $25(\mathrm{OH}) \mathrm{D}$ assessed (63). The method for measurement of 25(OH)D varied depending on South East Asian country, with two using one immunoassay, another country used a different immunoassay and the fourth country used HPLC. The prevalence of serum $25(\mathrm{OH}) \mathrm{D}<25 \mathrm{nmol} / \mathrm{L}$ was $0,4.1,2.0$ and $11.1 \%$ for Indonesia, Malaysia, Thailand and Vietnam, respectively, and $44,39.6,31.7$, and $37.1 \%$ with serum $25(\mathrm{OH}) \mathrm{D}$ between 25 and $50 \mathrm{nmol} / \mathrm{L}$, respectively. These estimates were not adjusted for seasonality.

It is clear from the estimates presented above that the prevalence of low vitamin $D$ status (as defined by use of the various serum $25(\mathrm{OH}) \mathrm{D}$ thresholds) varies considerably by geographic location within the globe as well as by race/ ethnicity and in some cases age group, whereas, in general, differences by gender are more modest or absent. Without good representative data for all of the world's regions, it is difficult to make truly valid comparisons on prevalence of vitamin D deficiency and inadequacy. Acknowledging this important point, data from the limited number of available representative surveys within various countries from around the globe might suggest a relatively low prevalence of serum $25(\mathrm{OH}) \mathrm{D}<25 / 30 \mathrm{nmol} / \mathrm{L}$, as indicative of increased risk of vitamin D deficiency, in South America (median; range, 3\%; 3-21\%), Oceania (median; range, $5 \% ; 5-6 \%)$ as well as North America (median; range, 7\%; $5-9 \%)$, whereas there is more moderate prevalence in Europe (13\%) and Asia (median; range, 18\%; 3-45\%). The prevalence may also be moderate in Africa ( 19\%), but it is important to stress again that this is based on metaanalysis of individual studies as opposed to being based on representative survey data. Even though the percentage estimates are low to moderate, this translates into hundreds of millions of individuals, and numbers that are increased by a factor of anything from 2 to $~ 10$, one should use serum $25(\mathrm{OH}) \mathrm{D}<50 \mathrm{nmol} / \mathrm{L}$ to reflect low vitamin $\mathrm{D}$ status. The remainder of the review will explore some of the issues contributing to such global differences in status.

\section{Differences in ultraviolet B availability and impact on vitamin D status globally}

There is no one single underlying reason for vitamin $\mathrm{D}$ deficiency, but the combination of low UVB availability and/or exposure coupled with a low-dietary vitamin D supply is of key importance (4). Before reviewing the data

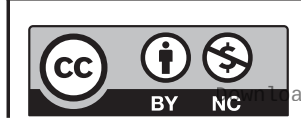

This work is licensed under a Creative Commons Attribution-NonCommercial 4.0 International License. ded from Bioscientifica.com at 04/26/2023 01:39:30PM 

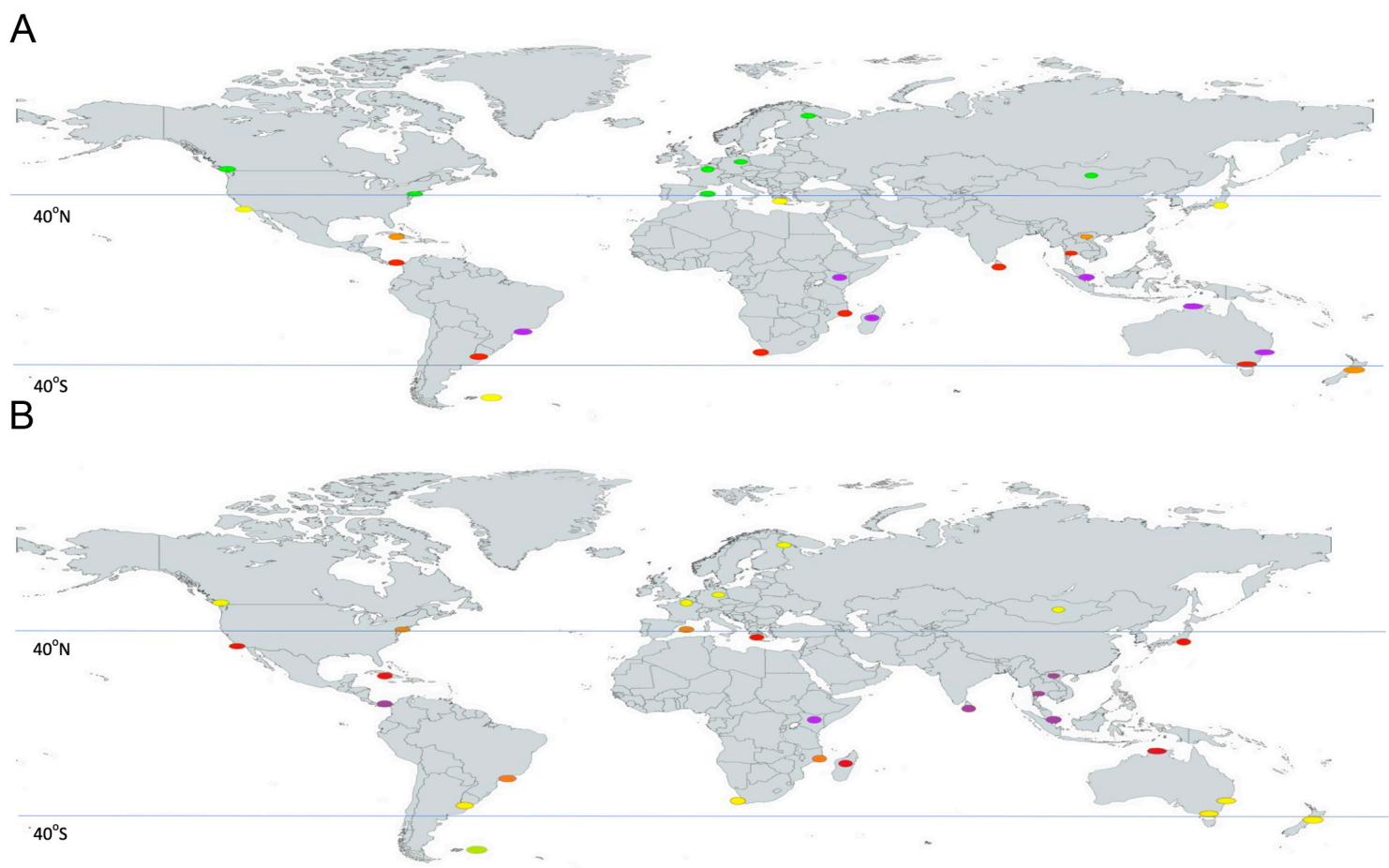

\section{Figure 4}

UV index scores* in capital cities across the globe during November to March (Panel A) and April to October (Panel B). *Represented by coloured ovals at the location (green, yellow, orange, red and violet representing UVI scores of 1-2, 3-5, 6-7, 8-10 and 11+, respectively).

on vitamin D intakes in the different world regions, it is worth considering differences in availability in UVB that may exist in these regions. Data from the WHO in relation to UV index (UVI) scores from capital cities of a selection of countries across the globe (64), as a crude estimate of availability of UVB for pre-vitamin $\mathrm{D}_{3}$ synthesis in exposed skin in individuals residing in these regions, are shown in Fig. 4 . The average monthly values were used to generate 'extended winter' and 'extended summer' UVI scores for each city at their variety of latitudes. The higher the UVI scores, the higher the availability of UVB radiation, and UVI readings of $1-2,3-5,6-7,8-10$ and $11+$ are considered low, moderate, high, very high and extreme, respectively. As a general rule, UVI scores $\geq 3$ are associated with the need for sun protection measures (65). Extended winter UVI scores (those from November to March in the Northern Hemisphere; April to October in the Southern Hemisphere) for those cities residing at latitudes $\geq 40^{\circ}$ were generally in the range of 1-2, irrespective of Hemisphere. For extended summer, the UVI scores in these same cities were in the range 3-7, indicative of ample UVB availability. UVI scores for those cities residing in the tropical latitudinal band between $\sim 30^{\circ} \mathrm{N}$ and $\sim 30^{\circ} \mathrm{S}$ (covering considerable portions of meso- and South America, Africa and Asia as well as some of Australia) were in the range of 6-11+ throughout the year, suggesting high year-round availability of UVB radiation (Fig. 4). It is important to stress that beyond environmental vitamin D-effective UVB availability, personal characteristics, such as skin pigmentation, age, attire, sunscreen usage, working environment, outdoor physical activity and sun exposure behaviour, can also prevent or impede vitamin D synthesis $(4,66)$.

There is a very clear translation between the changes in UVB availability during the year and seasonal changes in vitamin D status and prevalence of vitamin D deficiency/ inadequacy in regions $\geq 40^{\circ}$. Prevalence estimates from the EU-based surveys (all $>47^{\circ} \mathrm{N}$ ) which have standardised serum $25(\mathrm{OH}) \mathrm{D}$ highlight this, whereby the percentage with serum $25(\mathrm{OH}) \mathrm{D}<30 \mathrm{nmol} / \mathrm{L}$ is in the range of $19.7-$ $31.8 \%$ (dependent on the survey) during extended winter and in the range 5.7-15.3\% during extended summer (30). In the Southern Hemisphere, a significant portion of New Zealand resides at $>40^{\circ} \mathrm{S}$, and its $2008 / 09$ national survey shows that the prevalence of serum $25(\mathrm{OH}) \mathrm{D}<25 \mathrm{nmol} / \mathrm{L}$ was $\sim 16 \%$ in September (late winter) vs $\sim 0 \%$ in March (late summer) (41). The magnitude of seasonal changes in the prevalence of low vitamin D status in countries/regions in the more tropical zone, where UVB availability is more abundant, is less clear as many of the studies referred to in this review did not report. The reviews of vitamin D status 
globally do provide some evidence of seasonality but are based on data across different studies, and even when data are provided within a study, these, in general, were individual studies, not representative studies $(25,66)$.

Whether this seasonal cycling of vitamin D status has consequences for health is not entirely clear. It has been suggested that it is conceivable that annually recurring cycles of low vitamin $\mathrm{D}$ and mild secondary hyperparathyroidism during the winter months contribute, at least in part and over many years, to age-related bone loss (67). This bone loss could arise from a winter-based increase in the rate of bone turnover due to low vitamin D status. For example, an increased seasonal fluctuation in serum 25(OH)D has been shown to be associated with increased levels of parathyroid hormone and C-terminal telopeptide, a marker of bone resorption (68). Large fluctuations in serum $25(\mathrm{OH}) \mathrm{D}$ have also been hypothesised to influence risk of certain types of cancer (69).

In the absence of sufficient UVB availability/exposure to enable synthesis in the skin, dietary supply of vitamin $\mathrm{D}$ is critical to meeting population requirements and prevention of vitamin D deficiency (4). Vitamin D does occur in the diet, both naturally and as an added nutrient for fortification, and in nutritional supplements. The remainder of this review will briefly overview vitamin D intakes in the same five major FAO regions of the globe. The estimated average requirement (EAR) for vitamin D for those aged $\geq 1$ years is $10 \mu \mathrm{g} /$ day (1), and, by convention, the percentage of the population with a habitual daily vitamin D intake lower than this is taken as an estimate of the percentage of the population with probable inadequate intakes.

\section{Global differences in vitamin D intakes}

It should be noted that just as the methodology for the measurement of $25(\mathrm{OH}) \mathrm{D}$ can impact the assessment of estimates of vitamin D status, and comparisons across countries/regions as well as even over time within a country (12), likewise, methodology used to assess dietary intake of vitamin D will impact on the estimates. Furthermore, whether surveys/studies capture vitamin D supplement use will also colour estimates of vitamin D intake.

\section{The Americas and Europe}

As was the case with serum $25(\mathrm{OH}) \mathrm{D}$ data, the US, Canada and Mexico within the North/Meso-American region as well as several member states in the European Union have representative data on vitamin $\mathrm{D}$ intake.
Data from the National Health and Nutrition Examination Survey 2011-2014 ( $\geq 1$ years, $n=16,180$ ) suggest that the mean intake of vitamin $\mathrm{D}$ from food and beverage sources was 4.9 $\mu \mathrm{g} /$ day (16). This estimate did not include the contribution from vitamin D-containing dietary supplements, which overall $37.4 \%$ of the population reported taking (16). Data from the earlier 2009-2012 cycle of the survey ( $\geq 2$ years, $n=16,975$ ) showed that the mean intake of vitamin $\mathrm{D}$ from all sources (naturally occurring in foods plus enriched/ fortified plus dietary supplements) was $6.6 \mathrm{mg} /$ day $(5.4 \mathrm{\mu g} /$ day excluding supplements), and $72.5 \%$ of individuals had intakes <EAR (70). While the reported vitamin $\mathrm{D}$ intakes are not delineated by racial group, it is interesting to note that the percentage of dietary supplement use in the 2011-2014 survey cycle was highest among N-H white (43.7\%) and N-H Asian (41.2\%) compared to N-H black (24.8\%) and Hispanic individuals (22.0\%) (16). Furthermore, in the overall sample, the prevalence of serum $25(\mathrm{OH}) \mathrm{D}<30 \mathrm{nmol} / \mathrm{L}$ was $7.1,4.7$ and $2.6 \%$ in those with food and beverage-derived vitamin $\mathrm{D}$ intake in the range 0-2.0, 2.1-5.1 and $>5.1 \mu \mathrm{g} /$ day, respectively and was $6.9 \%$ in non-supplement users compared to $1.1 \%$ in supplement users (16).

Data from the Canadian Health Measures Survey 2015 ( $\geq 19$ years, $n=11,992$ ) (71) suggest mean intakes of vitamin D of 5.1 and $4.2 \mu \mathrm{g} /$ day for males and females, respectively, resulting in 94 and 98\%, respectively, with intakes $<$ EAR. There was very little variation in mean intakes across adult age groups. These estimates of vitamin D intake do not consider the contribution from supplement use. This is noteworthy as in 2015, approximately $34 \%$ of Canadians took a vitamin D supplement, rising from $~ 25$ to $30 \%$ in adults aged 31-50years to $36.9-45.8 \%$ in adults aged 71 and older (72). Data from the 2004 cycle of the survey suggest mean vitamin D intakes in the range of 7-9 $\mu \mathrm{g} /$ day for Canadian children aged 1-18 years, which were not included in this recent analysis (73). It should also be noted, however, that the mean intakes for adults aged 19+ years in the 2004 survey were higher (7.9 and $6.1 \mu \mathrm{g} /$ day for males and females, respectively) (73) than the 2015 estimates (71). The 2004 survey did not include the contribution of vitamin D from supplement use in its intake estimates.

Vitamin D intake data from a random sample of the 2012 ENSANUT survey in Mexico ( $n=10,886$ or $11.3 \%$ of the total survey sample) suggest a mean usual intake of $4.8 \mu \mathrm{g} /$ day for children aged both 1-4 and 5-11 years as well as adolescents (aged 12-18 years), whereas Mexican adults (aged $\geq 20$ years) had a mean intake of vitamin $D$ of $3.8 \mu \mathrm{g} /$ day (74). The survey did not include the contribution of vitamin D from supplement use. Not unsurprisingly 


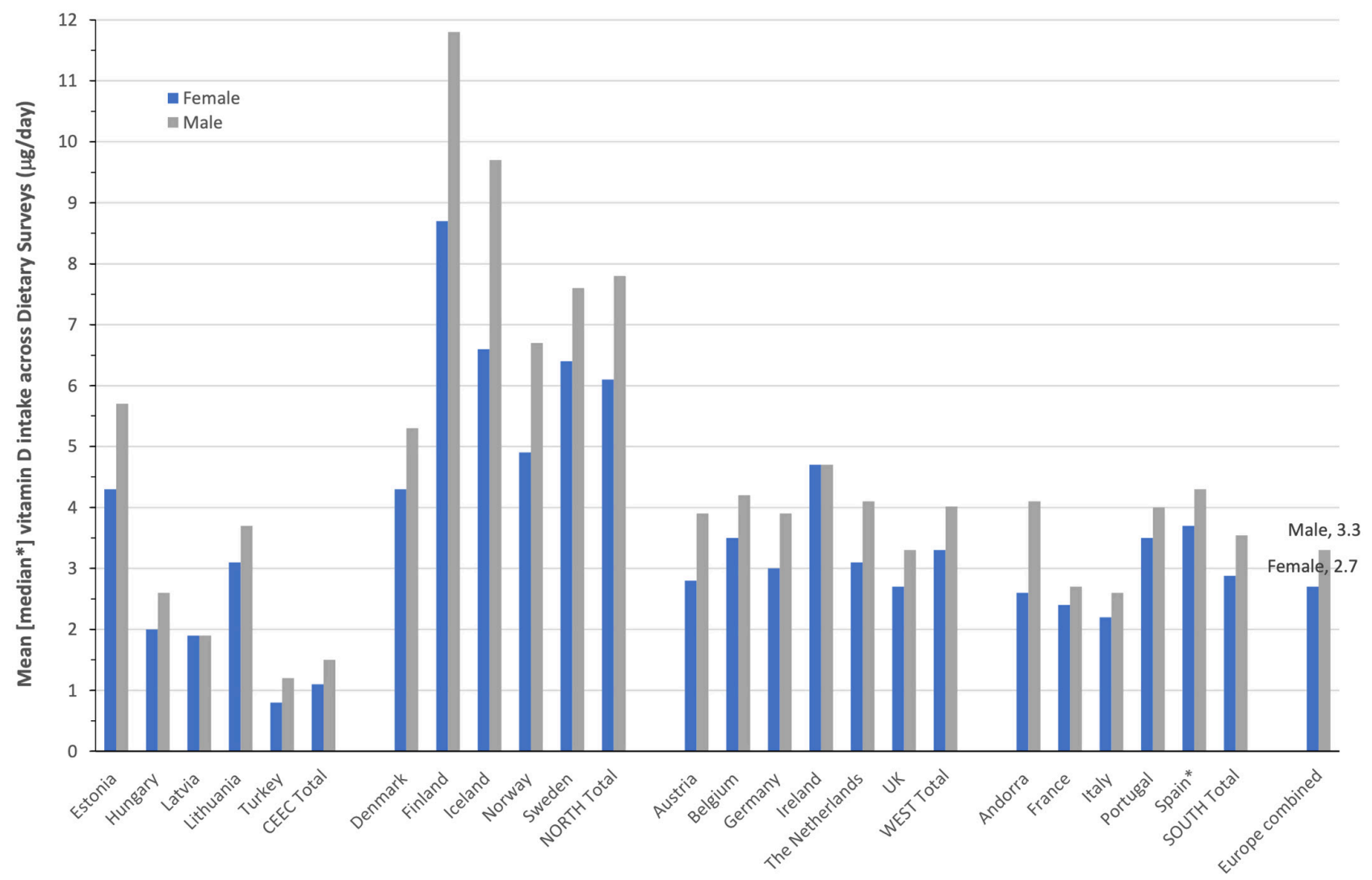

Figure 5

The mean (or median) vitamin D intake among European-based dietary surveys of adult males and females.

with these relatively low intakes, $95.7,94.5,93.0$ and $96.5 \%$ of young children (1-4 years), children (5-11 years), adolescents and adults, respectively, had vitamin D intakes below the EAR (74). While nationally representative data on vitamin D intake, such as that from the three North American countries mentioned above, are priority data as it can inform on the adequacy of dietary supply of vitamin $\mathrm{D}$ in a population, such data are lacking for a majority of countries, including countries in Central- and South America. Estimates of average per capita supply of vitamin $\mathrm{D}$, as calculated using information from the FAO national food balance sheets, can be used as proxy measures for vitamin D intake within a population as well as being able to highlight countries where inadequacy of supply may be of concern. A recent global mapping of per capita supply of vitamin D provides estimates for $\sim 170$ countries was published (15) and this included those in Central (Meso)and South America. In general, while much of South America and Meso-America had average per capita vitamin D supply estimates (not including supplemental vitamin D) in the range 1.6-5.5 $\mu \mathrm{g} /$ day (median of $2.4 \mu \mathrm{g} /$ day), the USA and Canada had estimates in the range 5.6-7.5 $\mu \mathrm{g} /$ day.
The above-mentioned 2018 review of national nutrition surveys within WHO European region identified those with vitamin D (and calcium) intake data (35), with the actual intake data (excluding that from supplements) published separately $(74,75)$. In the case of adults, intake data from 21 countries ranging from Northern, Western (including some Southern) and Central and Eastern Europe were available for males and females, and all were relatively recent, being conducted within a window between 2004 and 2015. For illustration purposes in this review, the Southern European countries are presented separately from the Western European countries (see Fig. 5). Taking all intake data across the 21 European surveys of adults would suggest relatively low intakes on average, with 2.7 and $3.3 \mu \mathrm{g} /$ day for females and males, respectively. However, there were very evident regional differences, with average intakes for females and males in the North (6.1 and $7.8 \mu \mathrm{g} /$ day, respectively) higher than those of Western (3.3 and $4.0 \mu \mathrm{g} /$ day, respectively) and Southern Europe (2.9 and $3.5 \mu \mathrm{g} /$ day, respectively), and which, in turn, were higher than those of Central and Eastern Europe (1.1 and $1.5 \mu \mathrm{g} /$ day, respectively). 


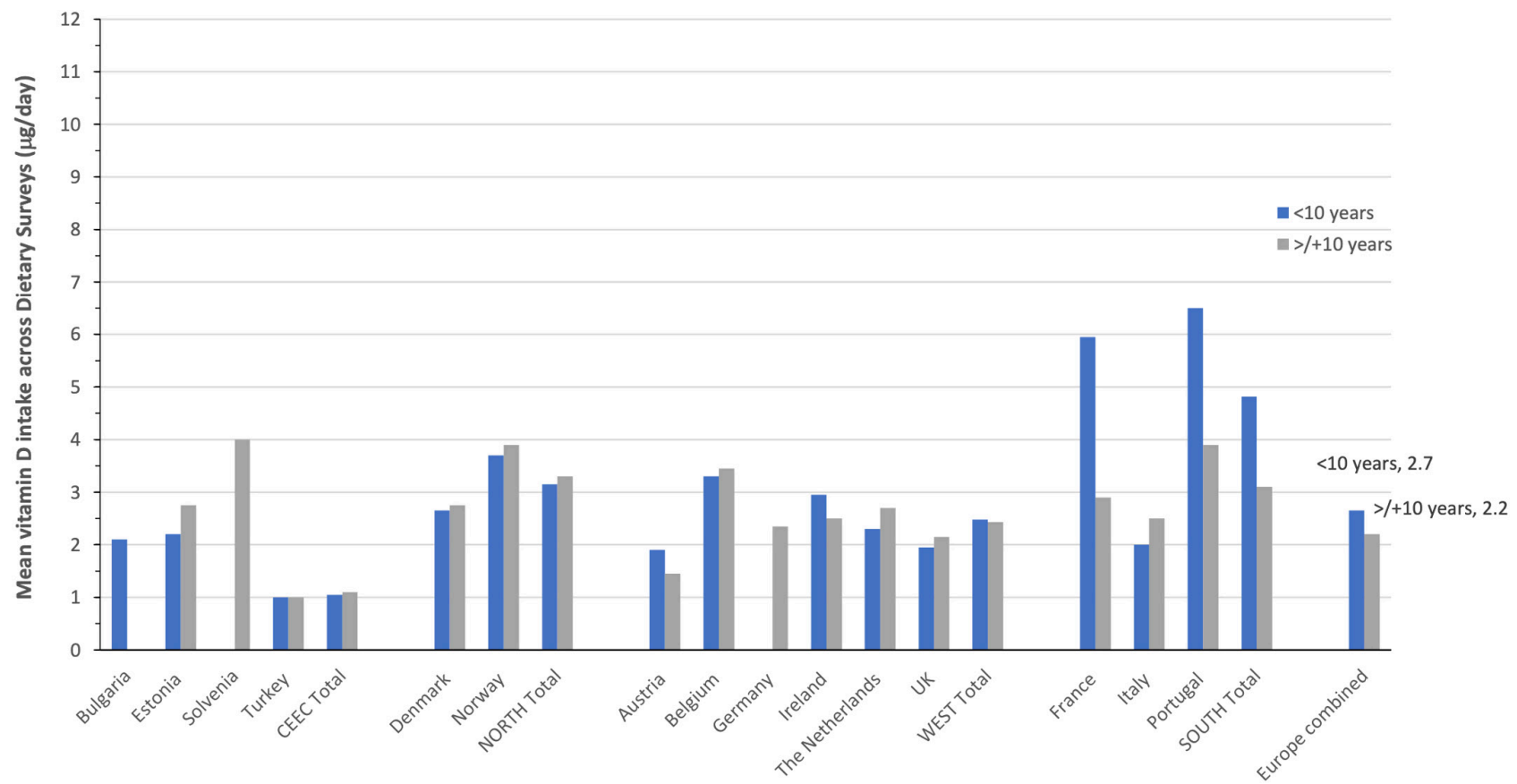

Figure 6

The mean vitamin D intake among European-based dietary surveys of children aged $<10$ and $\geq 10$ years.

Even within a region, there was variability in mean intakes between constituent countries, especially for Northern Europe and Central and Eastern Europe (Fig. 5). While the prevalence of vitamin D intakes less than the EAR of 10 $\mu \mathrm{g} /$ day was not provided, it is clear from the mean intakes that, bar possibly Finland, most will have a high majority with an inadequate intake of vitamin D.

In the case of children, vitamin D intake data from 13 countries across Europe were available for males and females and for those aged $<10$ and $\geq 10$ years. All the surveys were relatively recent, being conducted within a window between 2003 and 2016. Again for illustration purposes, the Southern European countries are presented separately from the Western European countries and the average intake of males and females within an age grouping that were used as gender differences was relatively minor for the most part (see Fig. 6). Taking all intake data across the 13 European surveys of children would suggest relatively low intakes on average, with 2.7 and $2.2 \mu \mathrm{g}$ /day for those aged $<10$ and $\geq 10$ years, respectively. Notable age-group differences in vitamin $\mathrm{D}$ intake were only evident in two of the three Southern European countries (Fig. 6). Average intakes for children aged $<10$ and $\geq 10$ years in the South (4.8 and $3.1 \mu \mathrm{g} /$ day, respectively) were modestly higher than those of the North (3.2 and $3.3 \mu \mathrm{g} /$ day, respectively) and higher than those of Western Europe (2.5 and
$2.4 \mu \mathrm{g}$ /day, respectively), and which, in turn, were higher than those of Central and Eastern Europe $(1.1 \mu \mathrm{g} /$ day for both age groups). While the prevalence of vitamin $\mathrm{D}$ intakes less than the EAR of $10 \mu \mathrm{g}$ /day were not provided, it is clear from the mean intakes that all will have a high majority with an inadequate intake of vitamin D.

\section{Oceania}

Unfortunately, the Australian Health Survey 2011/12 and 2008/09 New Zealand Adult Nutrition Survey considered the food composition data for vitamin D as insufficiently reliable and consequently did not present vitamin D intake estimates. Liu et al., after generating new vitamin D compositional data for animal-derived foods in Australia, applied these to the 2011-2012 Australian Health Survey and the resulting estimate for those aged $\geq 18$ years was $4.3 \mu \mathrm{g} /$ day (76). This estimate was derived from (animal) food sources only and did not include the contribution of supplements to vitamin D intake. Data from the same survey show that the prevalence of vitamin D-containing supplement use was 10, 6, 13-18 and $21-25 \%$ in children, adolescents, adults (18-50 years) and older adults (51-70 and 71+ years), respectively, and overall within adults, females (24\%) had a higher prevalence of usage than males (13\%) (77). The global mapping of per capita supply
This work is licensed under a Creative Commons Attribution-NonCommercial 4.0 International License. ded from Bioscientifica.com at 04/26/2023 01:39:30PM via free access 
of vitamin D provides estimates for countries in Oceania beyond the Australia and New Zealand, which are in the range 2.5-7.6 $\mu \mathrm{g} /$ day, median of $5.2 \mu \mathrm{g} /$ day (15).

\section{Africa and Asia}

Vitamin D intake data for countries in Africa and Asia are very sparse, and particularly data from representative studies. Mean daily intake estimates for vitamin D were reported for Malaysian children as part of the SEANUTS Malaysia, stratified by age group and urban vs rural setting (61). For infants (0.5-0.9 years), children aged 1-3.9, 4.06.9 and 7.0-12 years, the mean vitamin D intake in urban settings was 5.9, 6.3, 5.5 and $5.5 \mu \mathrm{g} /$ day, respectively and 7.3, 6.7, 5.7 and $4.6 \mu \mathrm{g} /$ day, respectively, in rural settings.

Cognizant of the limitations of the per capita vitamin D supply estimate approach, the global mapping exercise has shown that the median per capita vitamin D supply estimates for all constituent countries within Africa and Asia were 1.4 and $2.8 \mu \mathrm{g} /$ day, respectively, as compared to 4.1 and $4.7 \mu \mathrm{g} /$ day for Europe and Oceania, respectively (15). There are very few food sources rich in vitamin D. Fish and fish products make up 70 and $78 \%$ of the foods codes in the UK's food composition database with vitamin D contents in the range of 5-10 and $>10 \mu \mathrm{g} / 100 \mathrm{~g}$, respectively (78). The per capita daily supply of fish was higher in Asia than Africa, which might explain some of the difference in vitamin D supply estimates. Within the African region, the vitamin $\mathrm{D}$ supply estimates in individual countries were variable, but a majority were in the range $<1.5-3 \mu \mathrm{g} /$ day and a minority were in the range 3.1-5.5 mg/day. Likewise, the vitamin D supply estimates in Asia were very variable in the range $<1.5-10 \mu \mathrm{g} / \mathrm{day}$, with a majority in the range $<1.5-5.5 \mu \mathrm{g} /$ day.

It is clear from the estimates presented above that the usual intakes of vitamin $\mathrm{D}$ can vary by geographic location within the globe, whereas, in general, differences by gender and age group are very modest. Some of the differences in vitamin $\mathrm{D}$ intake in different world regions relate to differences in the supply of animal-derived foods, particularly fish, eggs, meat and fortified milk and milk products, being higher among the high-income countries (15). Variable food fortification practises in different world regions, ranging from absent to mandatory, will also impact the food supply of vitamin D (15). It should also be noted that for several of the nationally representative surveys mentioned in this review, supplemental vitamin D was not included in the vitamin D intake estimates and thus are underestimates of total vitamin D intakes in their population. There is some evidence that vitamin D supplement use may have increased during the COVID-19 pandemic $(79,80)$. In general, with a few exceptions, there are very high levels of inadequacy of vitamin D intake within populations around the globe, as represented by vitamin D intakes below the EAR of $10 \mu \mathrm{g} /$ day (1). It is for this reason, we had suggested the development of sustainable food-based strategies to bridge the gap between current and recommended intakes of vitamin $\mathrm{D}$ to minimise the prevalence of vitamin $\mathrm{D}$ deficiency as our third prioritising research requirements a decade ago (2). This topic has been reviewed elsewhere $(4,81,82)$ and is beyond the scope of the present review.

\section{Conclusions}

Low vitamin D status occurs in populations across the globe but the burden of this varies, such that prevalence of serum $25(\mathrm{OH}) \mathrm{D}<25 / 30 \mathrm{nmol} / \mathrm{L}$ ranges from $\sim 5$ to $18 \%$, depending on FAO world region, and from 24 to $49 \%$ in the case of serum $25(\mathrm{OH}) \mathrm{D}<50 \mathrm{nmol} / \mathrm{L}$. Depending on the serum $25(\mathrm{OH}) \mathrm{D}$ threshold applied, these translate into hundreds of millions to billions of individuals globally. These prevalence estimates are based on data from nationally representative surveys which are key in terms of informing the magnitude of the public health issue of vitamin D deficiency around the globe. While some prevalence estimates are based on standardised serum $25(\mathrm{OH}) \mathrm{D}$ data, other estimates are not. Standardisation of $25(\mathrm{OH}) \mathrm{D}$ values is of high priority going forward so as to minimise method-related differences. It is notable that a vast majority of countries do not have such surveys and are missing representative data on the biochemical status and intake of vitamin D and other nutrients of public health concern. The 2020 Global Nutrition Report stressed that a major outstanding laggard is the little notable progress in the collection, analysis and use of micronutrient deficiency data (83). There has also been a call to action from the Micronutrient Forum in terms of increasing the availability and utilisation of reliable data on population micronutrient (including vitamin D) status globally (84). A lack of such data undermines a full understanding of the magnitude of the micronutrient deficiency problems and impedes their control programmes (84). Thus, there is a clear need for strategic investment in quality, accessible surveillance and bio-banking systems among very many countries globally. This need was also reflected recently in the highlevel research agenda flowing from a technical report on the global prevalence and disease burden of vitamin $\mathrm{D}$ deficiency in low- and middle-income countries (85). 
Thus, while an enormous amount of incredibly useful research has been undertaken and published in vitamin D's first 100 years of life, much still remains to be done so as to ensure that vitamin D deficiency truly becomes a thing of the past and as soon as possible.

\section{Declaration of interest}

The author declares that there is no conflict of interest that could be perceived as prejudicing the impartiality of this review.

\section{Funding}

This work did not receive any specific grant from any funding agency in the public, commercial or not-for-profit sector.

\section{References}

1 Institute of Medicine. Dietary Reference Intakes for Calcium and Vitamin D. Washington, DC, USA: The National Academies Press, 2011.

2 Cashman KD \& Kiely M. Towards prevention of vitamin D deficiency and beyond: knowledge gaps and research needs in vitamin D nutrition and public health. British Journal of Nutrition 2011106 1617-1627. (https://doi.org/10.1017/S0007114511004995)

3 Seamans KM \& Cashman KD. Existing and potentially novel functional markers of vitamin D status: a systematic review. American Journal of Clinical Nutrition 200989 1997S-2008S. (https://doi. org/10.3945/ajen.2009.27230D)

4 Cashman KD. Vitamin D deficiency: defining, prevalence, causes, and strategies of addressing. Calcified Tissue International 2020106 14-29. (https://doi.org/10.1007/s00223-019-00559-4)

5 Scientific Advisory Committee on Nutrition. Report on vitamin D and health, 2016. (available at: https://assets.publishing.service.gov.uk/ government/uploads/system/uploads/attachment_data/file/537616/ SACN_Vitamin_D_and_Health_report.pdf)

6 EFSA NDA Panel (EFSA Panel on Dietetic Products, Nutrition and Allergies). Scientific opinion on dietary reference values for vitamin D. EFSA Journal 201614 4547. (https://doi.org/10.2903/j.efsa.2016.4547)

7 Munns CF, Shaw N, Kiely M, Specker BL, Thacher TD, Ozono K, Michigami T, Tiosano D, Mughal MZ, Mäkitie O, et al. Global consensus recommendations on prevention and management of nutritional rickets. Journal of Clinical Endocrinology and Metabolism 2016101 394-415. (https://doi.org/10.1210/jc.2015-2175)

8 Holick MF, Binkley NC, Bischoff-Ferrari HA, Gordon CM, Hanley DA, Heaney RP, Murad MH, Weaver CM \& Endocrine Society. Evaluation, treatment, and prevention of vitamin D deficiency: an Endocrine Society clinical practice guideline. Journal of Clinical Endocrinology and Metabolism 201196 1911-1930. (https://doi.org/10.1210/jc.2011-0385)

9 NORDEN Nordic Nutrition Recommendations, 5th Edition (NNR5) vitamin D, 2012. (available at: https://norden.diva-portal.org/smash/ get/diva2:704251/FULLTEXT01.pdf)

10 German Nutrition Society. New reference values for vitamin D. Annals of Nutrition and Metabolism 201260 241-246. (https://doi. org/10.1159/000337547)

11 Cashman KD. Vitamin D requirements for the future - lessons learned and charting a path forward. Nutrients 201810 533. (https://doi. org/10.3390/nu10050533)

12 Sempos CT, Vesper HW, Phinney KW, Thienpont LM, Coates PM \& Vitamin D Standardization Program (VDSP). Vitamin D status as an international issue: national surveys and the problem of standardization. Scandinavian Journal of Clinical and Laboratory Investigation: Supplementum 2012243 32-40. (https://doi.org/10.3109/ 00365513.2012.681935)
13 Rabenberg M, Scheidt-Nave C, Busch MA, Thamm M, Rieckmann N, Durazo-Arvizu RA, Dowling KG, Škrabáková Z, Cashman KD, Sempos CT, et al. Implications of standardization of serum 25-hydroxyvitamin D data for the evaluation of vitamin D status in Germany, including a temporal analysis. BMC Public Health 201818 845. (https://doi.org/10.1186/s12889-018-5769-y)

14 Cashman KD, Kiely M, Kinsella M, Durazo-Arvizu RA, Tian L, Zhang Y, Lucey A, Flynn A, Gibney MJ, Vesper HW, et al. Evaluation of vitamin D standardization program protocols for standardizing serum 25-hydroxyvitamin D data: a case study of the program's potential for national nutrition and health surveys. American Journal of Clinical Nutrition 201397 1235-1242. (https://doi.org/10.3945/ajcn.112.057182)

15 Cashman KD. Global view of per capita daily vitamin D supply estimates as proxy measures for vitamin D intake data. JBMR Plus 2021 e10547. (https://doi.org/10.1002/jbm4.10547)

16 Herrick KA, Storandt RJ, Afful J, Pfeiffer CM, Schleicher RL, Gahche JJ \& Potischman N. Vitamin D status in the United States, 2011-2014. American Journal of Clinical Nutrition 2019110 150-157. (https://doi. org/10.1093/ajcn/nqz037)

17 Brooks SPJ, Greene-Finestone L, Whiting S, Fioletov VE, Laffey P \& Petronella N. An analysis of factors associated with 25-hydroxyvitamin $\mathrm{D}$ levels in white and non-white Canadians. Journal of AOAC International 2017100 1345-1354. (https://doi.org/10.5740/jaoacint.17-0250)

18 Sarafin K, Durazo-Arvizu R, Tian L, Phinney KW, Tai S, Camara JE, Merkel J, Green E, Sempos CT \& Brooks SP. Standardizing 25-hydroxyvitamin D values from the Canadian Health Measures Survey. American Journal of Clinical Nutrition 2015102 1044-1050. (https://doi.org/10.3945/ajcn.114.103689)

19 Flores M, Barquera S, Sanchez L, Lozada A, Macias N \& Diaz E. Concentraciones séricas de vitamina $\mathrm{D}$ en niños, adolescentes y adultos mexicanos resultados de la ENSANUT, 2006. (available at: https://siid.insp.mx/www/proyecto_detalle_v3.asp?id=1-591-6358)

20 Flores A, Flores M, Macias N, Hernández-Barrera L, Rivera M, Contreras A \& Villalpando S. Vitamin D deficiency is common and is associated with overweight in Mexican children aged 1-11 years. Public Health Nutrition 201720 1807-1815. (https://doi.org/10.1017/ S1368980017000040)

21 Contreras-Manzano A, Villalpando S \& Robledo-Pérez R. Vitamin D status by sociodemographic factors and body mass index in Mexican women at reproductive age. Salud Publica de México 201759 518-525. (https://doi.org/10.21149/8080)

22 Pérez-Zepeda MU, García-Peña C \& Carrillo-Vega MF. Individual and cumulative association of commonly used biomarkers on frailty: a cross-sectional analysis of the Mexican Health and Aging Study. Aging Clinical and Experimental Research 201931 1429-1434. (https://doi. org/10.1007/s40520-019-01127-4)

23 Robinson SL, Ramirez-Zea M, Roman AV, Villamor E \& Nine Mesoamerican Countries Metabolic Syndrome Study (NiMeCoMeS) Group. Correlates and family aggregation of vitamin D concentrations in school-aged children and their parents in nine Mesoamerican countries. Public Health Nutrition 201720 2754-2765. (https://doi. org/10.1017/S1368980017001616)

24 Brito A, Cori H, Olivares M, Fernanda Mujica M, Cediel G \& López de Romaña D. Less than adequate vitamin $\mathrm{D}$ status and intake in Latin America and the Caribbean: a problem of unknown magnitude. Food and Nutrition Bulletin 201334 52-64. (https://doi. org/10.1177/156482651303400107)

25 Palacios C \& Gonzalez L. Is vitamin D deficiency a major global public health problem? Journal of Steroid Biochemistry and Molecular Biology 2014144 138-145. (https://doi.org/10.1016/j.jsbmb.2013.11.003)

26 Solis-Urra P, Cristi-Montero C, Romero-Parra J, Zavala-Crichton JP, Saez-Lara MJ \& Plaza-Diaz J. Passive commuting and higher sedentary time is associated with vitamin D deficiency in adult and older women: results from Chilean National Health Survey 2016-2017. Nutrients 201911 300. (https://doi.org/10.3390/nu11020300) https://ec.bioscientifica.com https://doi.org/10.1530/EC-21-0282 (c) 2022 The author Published by Bioscientifica Ltd

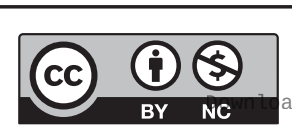

This work is licensed under a Creative Commons Attribution-NonCommercial 4.0 International License. ded from Bioscientifica.com at 04/26/2023 01:39:30PM 
27 Beer RJ, Herrán OF \& Villamor E. Prevalence and correlates of vitamin $\mathrm{D}$ deficiency in a tropical setting: results from a nationally representative survey. American Journal of Clinical Nutrition 2020112 1088-1098. (https://doi.org/10.1093/ajcn/nqaa197)

28 Hilger J, Friedel A, Herr R, Rausch T, Roos F, Wahl DA, Pierroz DD, Weber P \& Hoffmann K. A systematic review of vitamin D status in populations worldwide. British Journal of Nutrition $201411123-45$. (https://doi.org/10.1017/S0007114513001840)

29 van Schoor N \& Lips P. Global overview of vitamin D status. Endocrinology and Metabolism Clinics of North America 201746 845-870. (https://doi.org/10.1016/j.ecl.2017.07.002)

30 Cashman KD, Dowling KG, Škrabáková Z, Gonzalez-Gross M, Valtueña J, De Henauw S, Moreno L, Damsgaard CT, Michaelsen KF, Mølgaard C, et al. Vitamin D deficiency in Europe: pandemic? American Journal of Clinical Nutrition 2016103 1033-1044. (https://doi. org/10.3945/ajcn.115.120873)

31 Duarte C, Carvalheiro H, Rodrigues AM, Dias SS, Marques A, Santiago T, Canhão H, Branco JC \& da Silva JAP. Prevalence of vitamin $\mathrm{D}$ deficiency and its predictors in the Portuguese population: a nationwide population-based study. Archives of Osteoporosis 202015 36. (https://doi.org/10.1007/s11657-020-0695-x)

32 Cashman KD, Dowling KG, Škrabáková Z, Kiely M, Lamberg-Allardt C Durazo-Arvizu RA, Sempos CT, Koskinen S, Lundqvist A, Sundvall J, et al. Standardizing serum 25-hydroxyvitamin D data from four Nordic population samples using the vitamin D standardization program protocols: shedding new light on vitamin D status in Nordic individuals. Scandinavian Journal of Clinical and Laboratory Investigation 201575 549-561. (https://doi.org/10.3109/00365513.2015.1057898)

33 Hastie CE, Pell JP \& Sattar N. Vitamin D and COVID-19 infection and mortality in UK Biobank. European Journal of Nutrition 202160 545-548. (https://doi.org/10.1007/s00394-020-02372-4)

34 Kiely M \& Cashman KD. Summary outcomes of the odin project on food fortification for vitamin D deficiency prevention. International Journal of Environmental Research and Public Health 2018152342. (https://doi.org/10.3390/ijerph15112342)

35 Rippin HL, Hutchinson J, Evans CEL, Jewell J, Breda JJ \& Cade JE. National nutrition surveys in Europe: a review on the current status in the 53 countries of the WHO European region. Food and Nutrition Research 2018 62. (https://doi.org/10.29219/fnr.v62.1362)

36 Hribar M, Hristov H, Gregorič M, Blaznik U, Zaletel K, Oblak A, Osredkar J, Kušar A, Žmitek K, Rogelj I, et al. Nutrihealth Study: seasonal variation in vitamin D status among the Slovenian adult and elderly population. Nutrients 202012 1838. (https://doi.org/10.3390/nu12061838)

37 Malacova E, Cheang PR, Dunlop E, Sherriff JL, Lucas RM, Daly RM, Nowson CA \& Black LJ. Prevalence and predictors of vitamin D deficiency in a nationally representative sample of adults participating in the 2011-2013 Australian Health Survey. British Journal of Nutrition 2019121 894-904. (https://doi.org/10.1017/S0007114519000151)

38 Black LJ, Dunlop E, Lucas RM, Pearson G, Farrant B \& Shepherd CCJ. Prevalence and predictors of vitamin D deficiency in a nationally representative sample of Australian Aboriginal and Torres Strait Islander adults. British Journal of Nutrition 2021126 101-109. (https:// doi.org/10.1017/S0007114520003931)

39 Horton-French K, Dunlop E, Lucas RM, Pereira G \& Black LJ. Prevalence and predictors of vitamin $D$ deficiency in a nationally representative sample of Australian adolescents and young adults. European Journal of Clinical Nutrition 202175 1627-1636. (https://doi. org/10.1038/s41430-021-00880-y)

40 Rockell JE, Green TJ, Skeaff CM, Whiting SJ, Taylor RW, Williams SM, Parnell WR, Scragg R, Wilson N, Schaaf D, et al. Season and ethnicity are determinants of serum 25-hydroxyvitamin D concentrations in New Zealand children aged 5-14 y. Journal of Nutrition 2005135 2602-2608. (https://doi.org/10.1093/jn/135.11.2602)

41 Ministry of Health. Vitamin D Status of New Zealand Adults: Findings from the 2008/9 New Zealand Adult Nutrition Survey. Wellington, New Zealand: Ministry of Health, 2012.
42 Heere C, Skeaff CM, Waqatakirewa L, Vatucawaqa P, Khan AN \& Green TJ. Serum 25-hydroxyvitamin D concentration of IndigenousFijian and Fijian-Indian women. Asia Pacific Journal of Clinical Nutrition 201019 43-48. (available at: https://apjcn.nhri.org.tw/server/ APJCN/19/1/43.pdf)

43 Cashman KD, Sheehy T \& O’Neill CM. Is vitamin D deficiency a public health concern for low middle income countries? A systematic literature review. European Journal of Nutrition 201958 433-453. (https://doi.org/10.1007/s00394-018-1607-3)

44 Mogire RM, Mutua A, Kimita W, Kamau A, Bejon P, Pettifor JM, Adeyemo A, Williams TN \& Atkinson SH. Prevalence of vitamin D deficiency in Africa: a systematic review and meta-analysis. Lancet: Global Health 20208 e134-e142. (https://doi.org/10.1016/S2214109X(19)30457-7)

45 Bouillon R. Vitamin D status in Africa is worse than in other continents. Lancet: Global Health 20208 e20-e21. (https://doi. org/10.1016/S2214-109X(19)30492-9)

46 Gromova O, Doschanova A, Lokshin V, Tuletova A, Grebennikova G, Daniyarova L, Kaishibayeva G, Nurpeissov T, Khan V, Semenova Y, et al. Vitamin D deficiency in Kazakhstan: cross-sectional study. Journal of Steroid Biochemistry and Molecular Biology 2020199 105565. (https:// doi.org/10.1016/j.jsbmb.2019.105565)

47 Lips P, Cashman KD, Lamberg-Allardt C, Bischoff-Ferrari HA, Obermayer-Pietsch B, Bianchi ML, Stepan J, El-Hajj Fuleihan G \& Bouillon R. Current vitamin D status in European and Middle East countries and strategies to prevent vitamin D deficiency: a position statement of the European Calcified Tissue Society. European Journal of Endocrinology 2019180 P23-P54. (https://doi.org/10.1530/EJE-18-0736)

48 Uush T. Prevalence of classic signs and symptoms of rickets and vitamin D deficiency in Mongolian children and women. Journal of Steroid Biochemistry and Molecular Biology 2013136 207-210. (https:// doi.org/10.1016/j.jsbmb.2012.10.014)

49 Nutrition status of the population of Mongolia. Fifth National Nutrition Survey Report. (available at: https://www.unicef.org/ mongolia/NNS_V_undsen_tailan_eng.pdf)

50 Kim SY, Lee MH, Lim WJ, Kim SI \& Lee YJ. Associations of 25-hydroxyvitamin D levels and arthritis with sleep duration: the Korean national health and nutrition examination survey 2008-2014. Nature and Science of Sleep 202012 883-894. (https://doi.org/10.2147/NSS.S275464)

51 Park JH, Hong IY, Chung JW \& Choi HS. Vitamin D status in South Korean population: seven-year trend from the KNHANES. Medicine 201897 e11032. (https://doi.org/10.1097/MD.0000000000011032)

52 Zhang W, Stoecklin E \& Eggersdorfer M. A glimpse of vitamin D status in Mainland China. Nutrition 201329 953-957. (https://doi. org/10.1016/j.nut.2013.01.010)

53 Chen J, Yun C, He Y, Piao J, Yang L \& Yang X. Vitamin D status among the elderly Chinese population: a cross-sectional analysis of the 20102013 China national nutrition and health survey (CNNHS). Nutrition Journal 2017 16 3. (https://doi.org/10.1186/s12937-016-0224-3)

54 Wei J, Zhu A \& Ji JS. A comparison study of vitamin D deficiency among older adults in China and the United States. Scientific Reports 20199 19713. (https://doi.org/10.1038/s41598-019-56297-y)

55 Hu Y, Chen J, Wang R, Li M, Yun C, Li W, Yang Y, Piao J, Yang X \& Yang L. Vitamin D nutritional status and its related factors for Chinese children and adolescents in 2010-2012. Nutrients 20179 1024. (https:// doi.org/10.3390/nu9091024)

56 Akter S, Eguchi M, Kurotani K, Kochi T, Kashino I, Ito R, Kuwahara K, Tsuruoka H, Kabe I \& Mizoue T. Serum 25-hydroxyvitamin D and metabolic syndrome in a Japanese working population: the Furukawa Nutrition and Health Study. Nutrition 201736 26-32. (https://doi. org/10.1016/j.nut.2016.02.024)

57 Tanaka S, Kuroda T, Yamazaki Y, Shiraki Y, Yoshimura N \& Shiraki M. Serum 25-hydroxyvitamin D below $25 \mathrm{ng} / \mathrm{mL}$ is a risk factor for long bone fracture comparable to bone mineral density in Japanese postmenopausal women. Journal of Bone and Mineral Metabolism 2014 32 514-523. (https://doi.org/10.1007/s00774-013-0520-3)

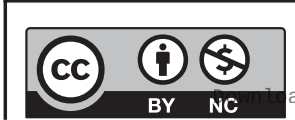

This work is licensed under a Creative Commons Attribution-NonCommercial 4.0 International License. ded from Bioscientifica com at 04/26/2023 01:39:30PM 
58 Nikooyeh B, Abdollahi Z, Shariatzadeh N, Kalayi A, Zahedirad M \& Neyestani T. Effect of latitude on seasonal variations of vitamin D and some cardiometabolic risk factors: national food and nutrition surveillance. Eastern Mediterranean Health Journal 202127 269-278. (https://doi.org/10.26719/emhj.20.119)

59 Nikooyeh B, Abdollahi Z, Hajifaraji M, Alavi-Majd H, Salehi F, Yarparvar AH \& Neyestani TR. Vitamin D status, latitude and their associations with some health parameters in children: national food and nutrition surveillance. Journal of Tropical Pediatrics 201763 57-64. (https://doi.org/10.1093/tropej/fmw057)

60 Chailurkit LO, Aekplakorn W \& Ongphiphadhanakul B. Regional variation and determinants of vitamin $D$ status in sunshineabundant Thailand. BMC Public Health 201111 853. (https://doi. org/10.1186/1471-2458-11-853)

61 Poh BK, Ng BK, Siti Haslinda MD, Nik SS, Wong JE, Budin SB, Ruzita AT, Ng LO, Khouw I \& Norimah AK. Nutritional status and dietary intakes of children aged 6 months to 12 years: findings of the Nutrition Survey of Malaysian Children (SEANUTS Malaysia). British Journal of Nutrition 2013110 (Supplement 3) S21-S35. (https://doi org/10.1017/S0007114513002092)

62 Al-Sadat N, Majid HA, Sim PY, Su TT, Dahlui M, Abu Bakar MF, Dzaki N Norbaya S, Murray L, Cantwell MM, et al. Vitamin D deficiency in Malaysian adolescents aged 13 years: findings from the Malaysian Health and Adolescents Longitudinal Research Team study (MyHeARTs). BMJ Open 20166 e010689. (https://doi.org/10.1136/bmjopen-2015-010689)

63 Poh BK, Rojroongwasinkul N, Nguyen BK, Sandjaja, Ruzita AT, Yamborisut U, Hong TN, Ernawati F, Deurenberg P, Parikh P, et al. 25-Hydroxy-vitamin D demography and the risk of vitamin D insufficiency in the South East Asian Nutrition Surveys (SEANUTS). Asia Pacific Journal of Clinical Nutrition 201625 538-548. (https://doi. org/10.6133/apjcn.092015.02)

64 The World Health Organization. INTERSUN: The Global UV Project: a guide and compendium. (available at: https://apps.who.int/iris/ bitstream/handle/10665/42814/9241591056.pdf)

65 Environmental Protection Agency. UV index scale. (available at: https://www.epa.gov/sunsafety/uv-index-scale-0)

66 Mithal A, Wahl DA, Bonjour JP, Burckhardt P, Dawson-Hughes B, Eisman JA, El-Hajj Fuleihan G, Josse RG, Lips P, Morales-Torres J, et al. Global vitamin D status and determinants of hypovitaminosis D. Osteoporosis International 200920 1807-1820. (https://doi.org/10.1007/ s00198-009-0954-6)

67 Meier C, Woitge HW, Witte K, Lemmer B \& Seibel MJ. Supplementation with oral vitamin D3 and calcium during winter prevents seasonal bone loss: a randomized controlled open-label prospective trial. Journal of Bone and Mineral Research 200419 1221-1230. (https://doi.org/10.1359/JBMR.040511)

68 Darling AL, Hart KH, Gibbs MA, Gossiel F, Kantermann T, Horton K, Johnsen S, Berry JL, Skene DJ, Eastell R, et al. Greater seasonal cycling of 25-hydroxyvitamin D is associated with increased parathyroid hormone and bone resorption. Osteoporosis International 201425 933-941. (https://doi.org/10.1007/s00198-013-2493-4)

69 Vieth R. How to optimize vitamin D supplementation to prevent cancer, based on cellular adaptation and hydroxylase enzymology. Anticancer Research 200929 3675-3684. (available at: https:// ar.iiarjournals.org/content/29/9/3675.long)

70 Newman JC, Malek AM, Hunt KJ \& Marriott BP. Nutrients in the US diet: naturally occurring or enriched/fortified food and beverage sources, plus dietary supplements: NHANES 2009-2012. Journal of Nutrition 2019149 1404-1412. (https://doi.org/10.1093/jn/nxz066)

71 Ahmed M, Praneet Ng A \& L'Abbe MR. Nutrient intakes of Canadian adults: results from the Canadian Community Health Survey (CCHS) 2015 public use microdata file. American Journal of Clinical Nutrition 2021114 1131-1140. (https://doi.org/10.1093/ajcn/nqab143)
72 Statistics Canada. Canadian community health survey - nutrition: nutrient intakes from food and nutritional supplements, 2017. (available at: https://www150.statcan.gc.ca/n1/dailyquotidien/170620/dq170620b-eng.htm)

73 Shakur YA, Lou W \& L'Abbe MR. Examining the effects of increased vitamin D fortification on dietary inadequacy in Canada. Canadian Journal of Public Health 2014105 e127-e132. (https://doi.org/10.17269/ cjph.105.4086)

74 Pedroza-Tobías A, Hernández-Barrera L, López-Olmedo N, GarcíaGuerra A, Rodríguez-Ramírez S, Ramírez-Silva I, Villalpando S, Carriquiry A \& Rivera JA. Usual vitamin intakes by Mexican populations. Journal of Nutrition 2016146 1866S-1873S. (https://doi. org/10.3945/jn.115.219162)

75 Rippin HL, Hutchinson J, Jewell J, Breda JJ \& Cade JE. Child and adolescent nutrient intakes from current national dietary surveys of European populations. Nutrition Research Reviews 201932 38-69. (https://doi.org/10.1017/S0954422418000161)

76 Liu J, Arcot J, Cunningham J, Greenfield H, Hsu J, Padula D, Strobel N \& Fraser DR. New data for vitamin D in Australian foods of anima origin: impact on estimates of national adult vitamin D intakes in 1995 and 2011-13. Asia Pacific Journal of Clinical Nutrition 201524 464-471. (https://doi.org/10.6133/apjcn.2015.24.4.04)

77 Black LJ, Jacoby P, Nowson CA, Daly RM \& Lucas RM. Predictors of vitamin D-containing supplement use in the Australian population and associations between dose and serum 25-hydroxyvitamin D concentrations. Nutrients 20168356 . (https://doi.org/10.3390/ nu8060356)

78 Cashman KD. Food-based strategies for prevention of vitamin $\mathrm{D}$ deficiency as informed by vitamin $\mathrm{D}$ dietary guidelines, and consideration of minimal-risk UVB radiation exposure in future guidelines. Photochemical and Photobiological Sciences 202019 800-809. (https://doi.org/10.1039/c9pp00462a)

79 Žmitek K, Hribar M, Lavriša Ž, Hristov H, Kušar A \& Pravst I. Sociodemographic and knowledge-related determinants of vitamin D supplementation in the context of the COVID-19 pandemic: assessment of an educational intervention. Frontiers in Nutrition 20218 648450. (https://doi.org/10.3389/fnut.2021.648450)

80 Hamulka J, Jeruszka-Bielak M, Górnicka M, Drywień ME \& ZielinskaPukos MA. Dietary supplements during COVID-19 outbreak. Results of google trends analysis supported by PLifeCOVID-19 online studies. Nutrients 202013 54. (https://doi.org/10.3390/nu13010054)

81 Hayes A \& Cashman KD. Food-based solutions for vitamin D deficiency: putting policy into practice and the key role for research. Proceedings of the Nutrition Society 201776 54-63. (https://doi. org/10.1017/S0029665116000756)

82 Cashman KD \& O'Dea R. Exploration of strategic food vehicles for vitamin D fortification in low/lower-middle income countries. Journal of Steroid Biochemistry and Molecular Biology 2019195 105479. (https:// doi.org/10.1016/j.jsbmb.2019.105479)

832020 Global Nutrition Report: Action on Equity to End Malnutrition. Bristol, UK: Development Initiatives. (available at: https:// globalnutritionreport.org/reports/2020-global-nutrition-report/)

84 Brown KH, Moore SE, Hess SY, McDonald CM, Jones KS, Meadows SR, Manger MS, Coates J, Alayon S \& Osendarp SJM. Increasing the availability and utilization of reliable data on population micronutrient (MN) status globally: the MN Data Generation Initiative. American Journal of Clinical Nutrition 2021114 862-870. (https://doi.org/10.1093/ajcn/nqab173)

85 Roth DE, Abrams SA, Aloia J, Bergeron G, Bourassa MW, Brown KH, Calvo MS, Cashman KD, Combs G, De-Regil LM, et al. Global prevalence and disease burden of vitamin D deficiency: a roadmap for action in lowand middle-income countries. Annals of the New York Academy of Sciences 20181430 44-79. (https://doi.org/10.1111/nyas.13968)

Received in final form 16 November 2021

Accepted 3 December 2021

Accepted Manuscript published online 3 December 2021 https://ec.bioscientifica.com https://doi.org/10.1530/EC-21-0282 (c) 2022 The author Published by Bioscientifica Ltd
This work is licensed under a Creative Commons Attribution-NonCommercial 4.0 International License. ed from Bioscientifica com at 04/26/2023 01:39:30PM 